\title{
1. EXPLANATORY NOTES, DEEP SEA DRILLING PROJECT LEG 93: LOWER AND UPPER CONTINENTAL RISE OFF EASTERN NORTH AMERICA ${ }^{1}$
}

\author{
Dean A. Dunn, Scripps Institution of Oceanography, and Department of Geology, \\ Univers: ${ }^{*} v$ of Southern Mississippi ${ }^{2}$
}

\section{INTRODUCTION}

Glomar Challenger departed from Norfolk, Virginia, on May 4, 1983, to drill the upper and lower continental rise of the northwestern Atlantic Ocean on DSDP Leg 93, and returned to Norfolk on June 17, 1983. Six holes were drilled at three sites during Leg 93 (Fig. 1), not counting the unsuccessful attempt to emplace a reentry cone at Hole 603A (Table 1).

\section{Site 603}

The original objective of this leg was to drill a deep hole (planned as ENA-3D) through sediments at the foot of the continental rise and to sample Jurassic basement. It was hoped that one reentry hole would obtain a complete sedimentary record dating from the initial opening of the North Atlantic to the present, showing the development and sedimentation processes of the North American Basin. Drilling in Hole 603B recovered strata of Miocene to Early Cretaceous (Valanginian) age, but because of operations difficulties the last few hundred meters of Jurassic sediments above basement were not cored.

At Site 603, Glomar Challenger rotary drilled and cored Holes 603 and 603B (a reentry hole), and used the variable length hydraulic piston corer (VLHPC) and extended core barrel (XCB) to recover the uppermost $366.0 \mathrm{~m}$ of the section in Hole $603 \mathrm{C}$. No sediment was recovered in the unsuccessful attempt to emplace a reentry cone and casing in Hole 603A (Table 1, Fig. 2).

\section{Sites 604 and 605}

Being unable to complete drilling and coring the stratigraphic section to basement at Site 603, Glomar Challenger was diverted to the upper continental rise off New Jersey, where it commenced drilling the New Jersey Transect at Sites 604 and 605 (Table 1). Two holes at Site 604 and one hole at Site 605 were drilled (Fig. 3); when combined, these holes provide a detailed record of late Maestrichtian to Quaternary sedimentation. A highlight of Site 605 drilling was the recovery of a Cretaceous/Tertiary boundary section in Section 605-66-1.

\section{Leg 95, Site 603, Holes 603D to 603F}

On Leg 95, Glomar Challenger returned to Site 603 from 1-15 September 1984, and drilled three holes (Ta-

\footnotetext{
1 van Hinte, J. E., Wise, S. W., Jr., et al., Init. Repts. DSDP, 93: Washington (U.S. Govt. Printing Office).

2 Present address: Department of Geology, University of Southern Mississippi, Southern Station Box 5044, Hattiesburg. MS 39406-5044.
}

ble 1, Fig. 2) in an unsuccessful attempt to deepen the record at this site below the $1585.2 \mathrm{~m}$ total depth in Hole 603B. Hole 603D was abandoned because of adverse weather conditions, and the destruction of the drill bit in Holes $603 \mathrm{E}$ and $603 \mathrm{~F}$ prevented completion of the cored sedimentary record in those holes.

Because Leg 95 drilling at Site 603 produced no significant scientific results, a brief discussion of Leg 95 operations and coring results is included in the site chapter for Leg 93, Site 603.

\section{ORGANIZATION AND AUTHORSHIP}

Volume 93 comprises two major sections. Volume 1 consists of these explanatory notes, the site report chapters, and physical properties data. Volume 2 contains more detailed discussions of topics from shipboard participants and interested shore-laboratory contributors, and is subdivided into paleontology (Part IV), sedimentology (Part V), inorganic geochemistry (Part VI), organic geochemistry (Part VII), and a synthesis section (Part VII), which includes a synopsis of the background, objectives, and principal results of the leg in a cruise summary by Wise and van Hinte.

The site chapters present the basic shipboard data and discussion of the sites drilled during Leg 93. The results of drilling at Sites 604 and 605 have been combined into a single chapter, and the Site 603 chapter also presents a brief discussion of the three holes drilled at this site during Leg 95. The authorship of these site chapters is collectively that of the shipboard scientific party, but ultimate responsibility lies with the Co-Chief Scientists, Jan E. van Hinte and Sherwood W. Wise, Jr. Each chapter follows the same general outline, and individual participants assumed the major responsibility for compiling specific sections. The site chapters are largely compiled on the basis of studies performed aboard ship during Leg 93, but additional information from onshore studies has been incorporated to provide a more complete and accurate report.

Individual sections of the Leg 93 site reports were compiled as follows. Authors responsible for each section are indicated in parentheses:

Site Summary Data

Introduction (Dunn)

Background and Objectives (van Hinte, Wise, and Dunn)

Operations (Wise, van Hinte, and Glen Foss, Leg 93 Cruise Operations Manager)

Lithology (Dunn, Haggerty, Ogg, Sarti, and von Rad) 


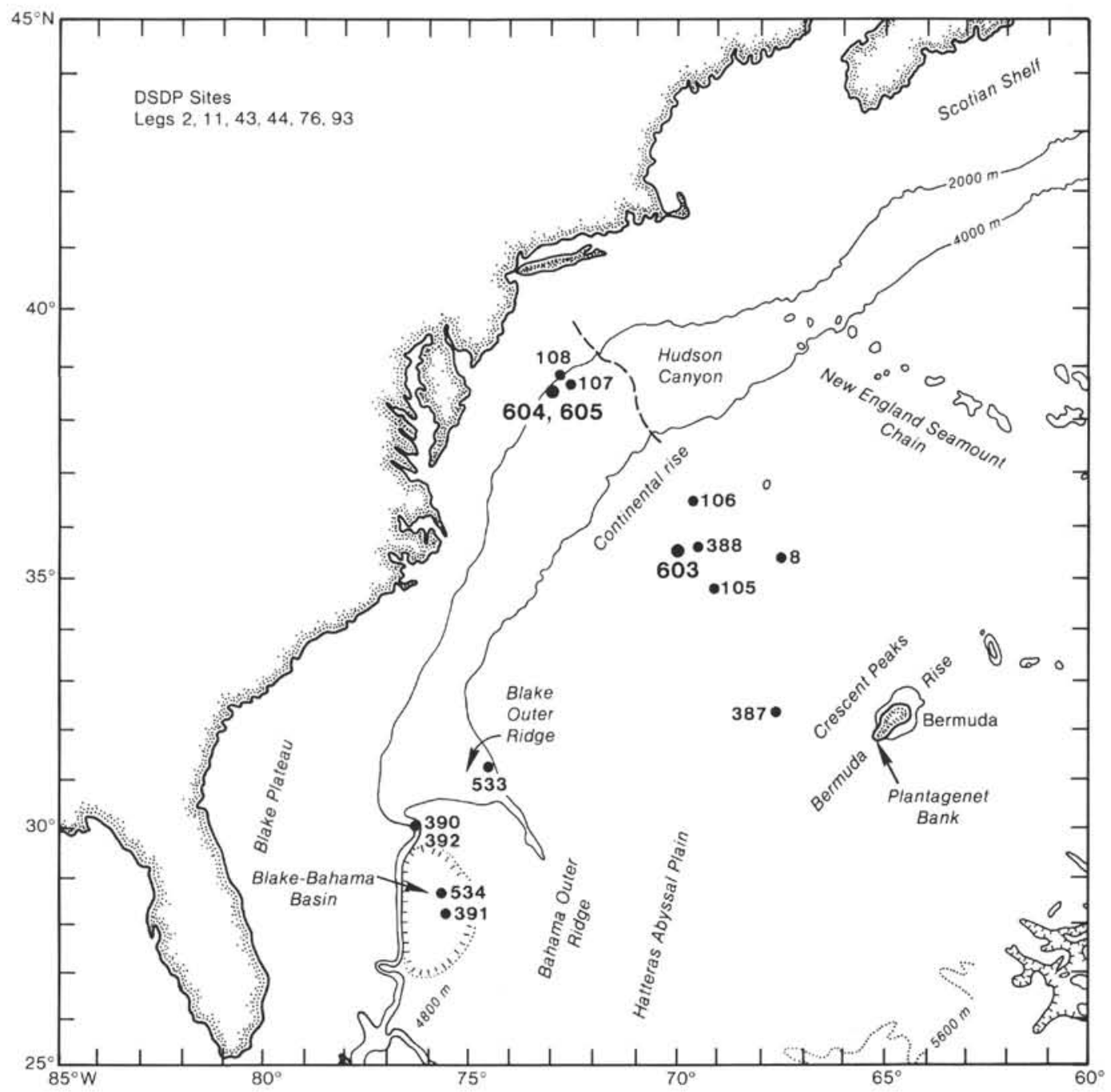

Figure 1. Location of DSDP sites drilled off the eastern coast of North America. During Leg 93, Site 603 was drilled on the lower continental rise, and Sites 604 and 605 were drilled on the upper continental rise.

Biostratigraphy:

Summary (Covington, Moullade, Muza, Okamura, van Hinte, and Wise)

Foraminifers (Moullade, with contributions from Hulsbos, Janssen, Kroon, Saint-Marc, and van Hinte)

Nannofossils (Muza, Covington, and Wise, with contributions from Lang)

Radiolarians (Okamura, with contributions from Nishimura and Dunn)

Diatoms (Abbott and Gombos)

Silicoflagellates (McCartney)

Sediment Accumulation Rates (Muza and van Hinte)

Geochemistry (Meyers)

Physical Properties (Biart and Johns)

Seismic Stratigraphy (van Hinte)

Summary and Conclusions (Wise and van Hinte)

A brief section on Leg 95 drilling at Site 603 follows the Leg 93, Site 603 compilation. Authors responsible for these Leg 95 sections are:

Background and Objectives (Poag and Watts)

Operations (Poag and Watts)
Lithology (Cousin, Mountain, Schiffelbein, Schreiber, and Thein)

Biostratigraphy (Hart, Miller, Palmer, and Valentine)

Organic Geochemistry (Nakamura and Tarafa)

Physical Properties (Wilkens)

Summary and Conclusions (Poag and Watts)

\section{SURVEY AND DRILLING DATA}

The seismic survey data that formed the basis of the selection of Site 603 (ENA-3D) were provided by Lamont-Doherty Geological Observatory and the Woods Hole Oceanographic Institution. An extensive multichannel survey by Knorr (Tucholke et al., 1982) made it possible to identify and locate target site ENA-3D at the boundary between the lower continental rise terrace and the lower continental rise hills. Final location of Site 603 was made by retracing multichannel seismic reflection line 77 (shot by Conrad on Cruise 21, Leg 1), using the Glomar Challenger's shipboard seismic profiling system to identify the targeted site location (Conrad 2101-77, $1731 \mathrm{hr}$., September 23, 1977). 
Table 1. Location of holes drilled at Site 603 by Legs 93 and 95 , and holes drilled at Sites 604 and 605 by Leg 93.

\begin{tabular}{|c|c|c|c|c|}
\hline Hole & $\begin{array}{l}\text { Latitude } \\
\text { (N) }\end{array}$ & $\begin{array}{l}\text { Longitude } \\
\text { (W) }\end{array}$ & $\begin{array}{c}\text { Water } \\
\text { depth } \\
(\mathrm{m})\end{array}$ & $\begin{array}{c}\text { Total } \\
\text { penetratio } \\
\text { (m) }\end{array}$ \\
\hline \multicolumn{5}{|c|}{ Leg 93, Site 603} \\
\hline 603 & $35^{\circ} 29.66^{\prime}$ & $70^{\circ} 1.70^{\prime}$ & 4634.0 & 832.6 \\
\hline $603 \mathrm{~A}$ & $29.69^{\prime}$ & $1.69^{\prime}$ & 4633.0 & 0.0 \\
\hline $603 \mathrm{~B}$ & $29.71^{\prime}$ & $1.71^{\prime}$ & 4633.5 & 1585.2 \\
\hline $603 \mathrm{C}$ & $29.78^{\prime}$ & $1.86^{\prime}$ & 4639.5 & 366.0 \\
\hline \multicolumn{5}{|c|}{ Leg 95, Site 603} \\
\hline 603D & $35^{\circ} 29.986^{\prime}$ & $70^{\circ} 1.407^{\prime}$ & 4641.0 & 639.7 \\
\hline $603 \mathrm{E}$ & $29.98^{\prime}$ & $1.367^{\prime}$ & 4641.0 & 1289.7 \\
\hline $603 \mathrm{~F}$ & $29.873^{\prime}$ & $1.357^{\prime}$ & 4640.0 & 1545.7 \\
\hline
\end{tabular}

Leg 93, Site 604

$$
604 \quad 39^{\circ} 42.79^{\prime} \quad 72^{\circ} 32.95^{\prime} \quad 2364.0 \quad 294.5
$$$$
\begin{array}{lllll}
604 \mathrm{~A} & 43.08^{\prime} & 33.64^{\prime} & 2340.0 & 284.4
\end{array}
$$

Leg 93, Site 605

$\begin{array}{lllll}605 & 38^{\circ} 44.53^{\prime} \quad 72^{\circ} 36.55^{\prime} & 2194.0 & 816.7\end{array}$

Note: Water depth is from sea level, as measured by drill string length.

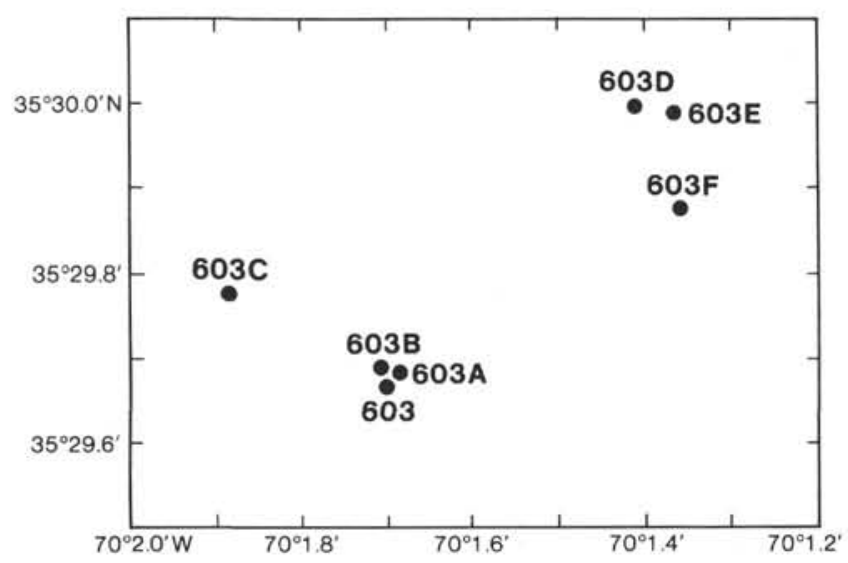

Figure 2. Location of holes drilled at Site 603 during Legs 93 and 95.

Leg 93 drilled Holes 603 through 603C, Leg 95, Holes 603D through $603 \mathrm{~F}$.

Because the circumstances that led to the drilling of Sites 604 and 605 were unforeseen, no original copies of seismic lines or site surveys were available aboard Glomar Challenger to aid the co-chief scientists in the selection of these sites. Site 604 was located by satellite navigation, using information telexed by DSDP to the ship, and by using the Challenger's seismic profiling system to retrace a U.S. Geological Survey multichannel seismic reflection survey line (U.S.G.S. line 35; see Fig. 3), a copy of which was photographically enlarged by the shipboard photographer from figure 53 of Schlee and Grow (1980). Site 604 was located just southeast of the illustrated portion of the line. Site 605 was located upslope from Site 604 by retracing U.S.G.S. multichannel seis- mic profile 25 , photographically enlarged from figure $8 \mathrm{a}$ of Klitgord and Grow (1980).

Instruments aboard Glomar Challenger continuously recorded water depth, intensity of the magnetic field, and seismic profiles while the ship was underway. Water depths were recorded underway on a GIFFT precision graphic recorder. The water depth (in $\mathrm{m}$ ) at each site was corrected according to the tables of Matthews (1939) and for the depth of the hull transducer $(6 \mathrm{~m})$ below sea level. When drill pipe lengths are measured from the derrick floor, a correction of $10 \mathrm{~m}$ is applied for the height of the floor above the water line. The site chapters contain the water depths from the bathymetric profiler system, the estimated depth to the derrick floor, and the length of drill pipe at which the seafloor was "felt" by the driller (seen by a change in the indicated weight on the drill bit).

The $12 \mathrm{kHz}$ bathymetric profiling system is supplemented with a $3.5 \mathrm{kHz}$ signal. The magnetic intensity data were collected with a Varian proton magnetometer, and readings were taken at 5 -min. intervals from an ana$\log$ recorder. The sensor was towed $300 \mathrm{~m}$ behind the ship. A Magnavox MX702A satellite navigation system was used for navigation.

The seismic profiling system consisted of one Bolt 580 water gun, Teledyne-designed hydrophone streamers, modified Bolt amplifiers, two bandpass filters, and two EDO dry paper recorders operated at different sweep rates and filter settings. Variations in second sweeps, filter and gain settings, and water-gun size are recorded on individual profiler records. Greenwich Mean Time (indicated by Z) is used on the seismic profiles and other underway data, but in order to be consistent with drilling logs and other ship's operations, the authors used "local time" (Eastern Daylight Savings Time) in the text of the site reports.

\section{DRILLING CHARACTERISTICS}

The depth at any level below the seafloor is the difference between the length of pipe needed to reach the seafloor (indicated in the summary data table for each site; see preceding discussions) and the length of pipe to the level in question. However, because of the presence of bumper subs (a type of splined shock absorber in the bottomhole assembly), the pipe can be telescoped about $3 \mathrm{~m}$ simply by increasing the weight on the bit. There is thus a small uncertainty in all of these depth measurements.

Because water circulation down the hole is open, cuttings are lost onto the seabed and cannot be examined. The only available information about sedimentary stratification between cores, other than from seismic data, is from an examination of the behavior of the drill string as observed on the drill platform. The harder the layer being drilled, the slower and more difficult it is to penetrate. A number of other variable factors, however, determine the rate of penetration, so it is not possible to relate this directly to the hardness of the layers. Among 


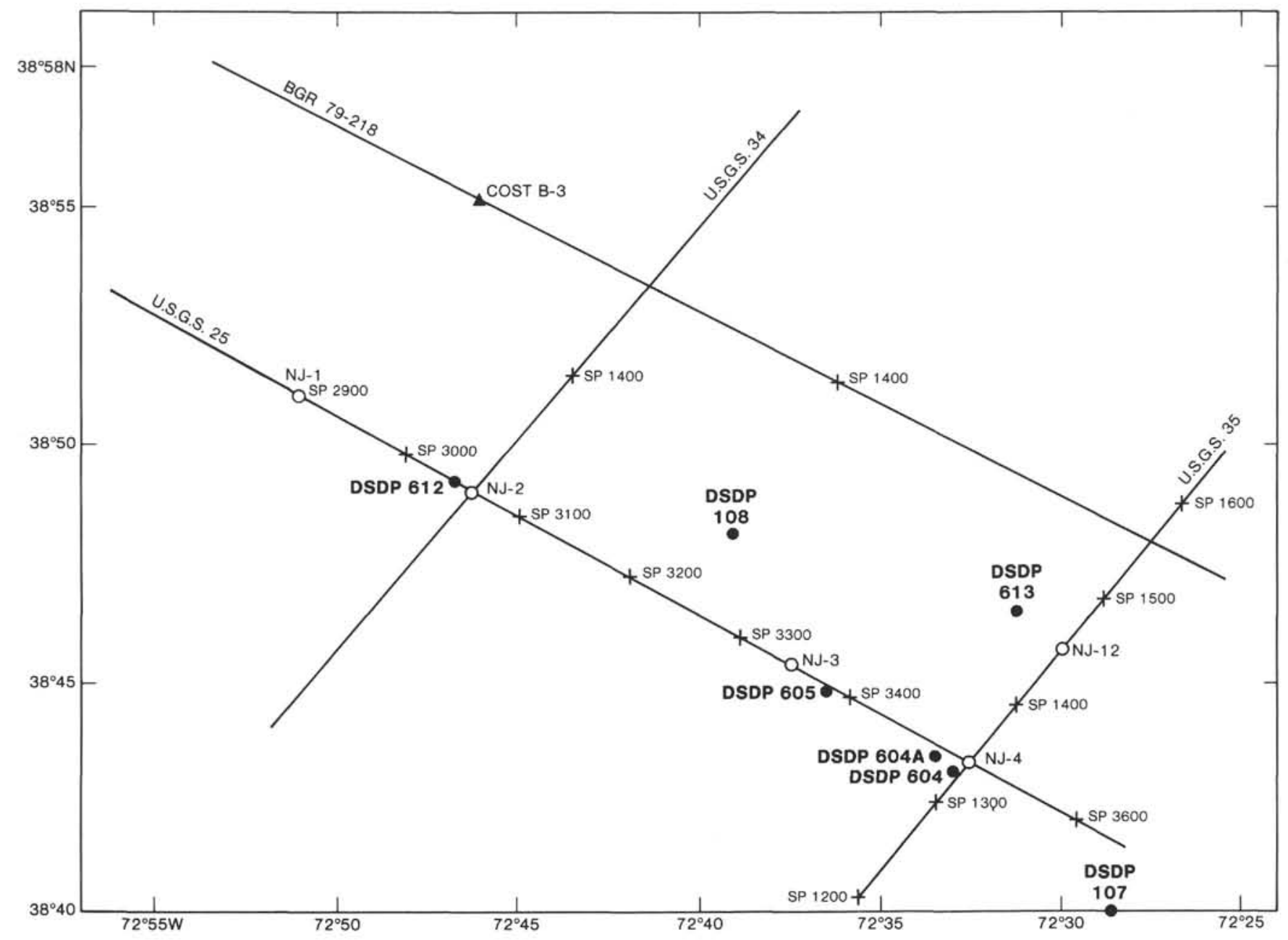

Figure 3. Location of U.S. Geological Survey multichannel seismic reflection lines 25, 34, and 35, German Geological Survey seismic reflection line BGR79-218, proposed DSDP drilling locations NJ-1 through NJ-4 and NJ-12, and DSDP sites actually drilled, on the upper continental rise off New Jersey. Sites 604 and 605 were drilled on the proposed New Jersey Transect during Leg 93, and Sites 612 and 613 were drilled by Leg 95 , to complete the transect.

these, the parameters of bit weight and revolutions per minute are recorded on the drilling recorder.

\section{Drilling Deformation}

When the cores are split, many show signs that the sediment has been disturbed since its deposition. Such signs include the concave-downward appearance of originally planar bands, the haphazard mixing of lumps of different lithologies, and the near-fluid state of some sediments recovered from tens or hundreds of meters below the seabed. It seems reasonable to suppose that this deformation came about during or after the cutting of the core. Three different stages during which the core may suffer stresses sufficient to alter its physical characteristics are cutting, retrieval (with accompanying changes in pressure and temperature), and core handling aboard ship.

\section{Hydraulic Piston Corer}

On Leg 93, the variable length hydraulic piston corer (VLHPC) was used successfully to recover undisturbed sediments in the uppermost $91.0 \mathrm{~m}$ of Hole $603 \mathrm{C}$. Recovery by HPC in this hole averaged $98.6 \%$, which was attributed to the low shear strength of the sediments. The hydraulic piston corer is located within the lowermost part of the drill string and is flush with the base of the drill bit before it is fired. Once fired, the cores ideally penetrate $9.6 \mathrm{~m}$ into the underlying sediment. The full extension of the HPC to this length is reflected on the rig floor by complete pressure bleed-off following the shot. After the sediment has been penetrated the HPC is pulled up $9.6 \mathrm{~m}$ to a position within the lowermost part of the drill string. The whole drill string is then raised to a point where a drill string tool joint appears on the level of the rig floor. The raised interval ranges from 0.0-9.5 m (length of one joint of drill- pipe). Thus a total open hole beneath the drill bit can be as high as $9.5 \mathrm{~m}+9.6 \mathrm{~m}$ or $19.1 \mathrm{~m}$. The drill string is then separated at the tool joint and the inner core barrel with the recovered sediment is pulled to the rig floor on the sand line.

After the core is removed, the HPC inner core is reloaded and returned to the base of the drill string. The length of the total sediment recovered by the HPC core barrel is measured, and the HPC drill bit then washes down through the sediment interval just previously cored, 
to a depth equal to the length of the recovered core. The last meter of lowering is done without washing. The base of the drill string is now at the desired level for the next HPC shot.

\section{Extended Core Barrel}

Leg 93 also utilized the Extended Core Barrel, previously used on Legs 84 and 90 . The XCB was used in Hole $603 \mathrm{C}$ to recover sediments that were too stiff to be cored by the HPC (Cores $12-40 ; 91.0-366.0 \mathrm{~m}$ sub-bottom). The XCB has been developed in response to a longrecognized need to recover undisturbed cores in the intermediate zone where the sediment is too hard for the piston corer yet still too soft to recover effectively by means of standard rotary coring. It is designed to continue in the same hole after the VLHPC becomes ineffective. Rotating with the drill string, the XCB employs a cutting shoe studded with Stratapax (artificial diamond) cutting discs which extends 6 in. below the drill bit. This allows the XCB to core soft sediments before they can be washed away by the drill bit jets. Harder sediments will cause the barrel to retract into the drill bit against the pressure of an internal spring, allowing indurated sediments to be cut predominantly by the roller cones and strong water jets of the drill bit (Fig. 4).

\section{SHIPBOARD SCIENTIFIC PROCEDURES}

\section{Numbering of Sites, Holes, Cores, Sections, and Samples}

DSDP drill sites are numbered consecutively from the first site drilled by Glomar Challenger in 1968. Site numbers are slightly different from hole numbers. A site number refers to one or more holes drilled while the ship was positioned over one acoustic beacon. These holes could be within a radius as great as $900 \mathrm{~m}$ from the beacon. Several holes may be drilled at a single site by pulling the drill pipe above the seafloor (out of one hole), moving the ship $100 \mathrm{~m}$ or more from the previous hole, and then drilling another hole.

A letter suffix distinguishes additional holes drilled at the same site. The first hole takes only the site number; the second takes the site number with suffix $A$; the third takes the site number with suffix B, and so forth. It is important, for sampling purposes, to distinguish the holes drilled at a site, because recovered sediments or rocks from different holes usually do not come from equivalent positions in the stratigraphic column.

The cored interval is measured in meters below the seafloor. The depth interval of an individual core is the depth below seafloor that the coring operation began to the depth that the coring operation ended. Each coring interval is generally $9.6 \mathrm{~m}$ long, which is the nominal length of a core barrel; however, the coring interval may be shorter. Particularly, the lengths of the uppermost 11 cores in Hole $603 \mathrm{C}$ are variable, because the VLHPC was used to recover these cores.

"Cored intervals" are not necessarily adjacent to each other, but may be separated by "drilled intervals." In soft sediment, the drill string can be "washed ahead" with the core barrel in place, but not recovering sedi- ment, by pumping water down the pipe at high pressure to wash the sediment out of the way of the bit and up the space between the drill pipe and wall of the hole. Occasionally, if thin, hard rock layers are present, it is possible to retain samples of these resistant layers within the washed interval, producing a core representing more than $9.5 \mathrm{~m}$.

Because Leg 93 was designed to attain deep penetration in a reentry hole, many intervals were washed ahead for more than $9.5 \mathrm{~m}$. Material remaining in the core barrel from these washed intervals was retained and was given a core number in sequence with the rest of the sediments from the hole, but with the suffix " $M$ " added to denote that these cores contain miscellaneous material. For example, Core 603B-1M contains $8.94 \mathrm{~m}$ of sediment recovered by washing from $0.0-285.0 \mathrm{~m}$ sub-bottom. Wash ("M") cores obtained during Leg 93 drilling are listed in Table 2 . Note that although wash cores from Leg 93 are in numerical sequence with cores obtained by other coring processes, the sub-bottom depths of materials in wash cores cannot be specified within the washed interval.

All cores taken from a hole are numbered serially from the top of the hole downward. Full recovery for a single core is normally $9.28 \mathrm{~m}$ of sediment or rock in a plastic liner with a $6.6 \mathrm{~cm}$ inner diameter, plus about $0.2 \mathrm{~m}$ (without a plastic liner) in the core catcher (the device at the bottom of the core barrel that prevents the core from sliding out when the barrel is being retrieved from the hole). The sediment core in the plastic liner is cut into $1.5-\mathrm{m}$ sections and numbered serially from the top of the sediment core (Fig. 5). When full recovery is obtained, the sections are numbered from 1 through 7 , the deepest section possibly being shorter than $1.5 \mathrm{~m}$. The corecatcher sample is placed below the last section when the core is described and labeled CC; it is treated as a separate section (for sediments only).

When recovery is less than $100 \%, 1.5$-m sections are numbered serially, starting with Section 1 at the top of the recovered material. There will be as many sections as are needed to accommodate the length of the core recovered (Fig. 5); for example, $3 \mathrm{~m}$ of core sample in the plastic liner will be divided into two $1.5-\mathrm{m}$ sections.

When recovery is less than $100 \%$, the original stratigraphic position of the sediment in the cored interval is unknown; for convenience in data handling and for consistency, we attribute the top of the recovered sediment to the top of the core interval. If recovery is less than $100 \%$, if the core is fragmented, and if shipboard scientists believe that the fragments were not originally contiguous, then sections are numbered serially and the intervening sections are noted as void, whether the fragments as found were contiguous or not.

Samples are designated by distances in centimeters from the top of each section to the top and bottom of the sample in that section. A full identification number for a sample consists of the following information: leg, site, hole, core, section, and interval in centimeters. For example, the sample identification number "93-603B-77-4, 98-102 cm" means that a sample was taken between 98 and $102 \mathrm{~cm}$ from the top of Section 4 of Core 77, from 


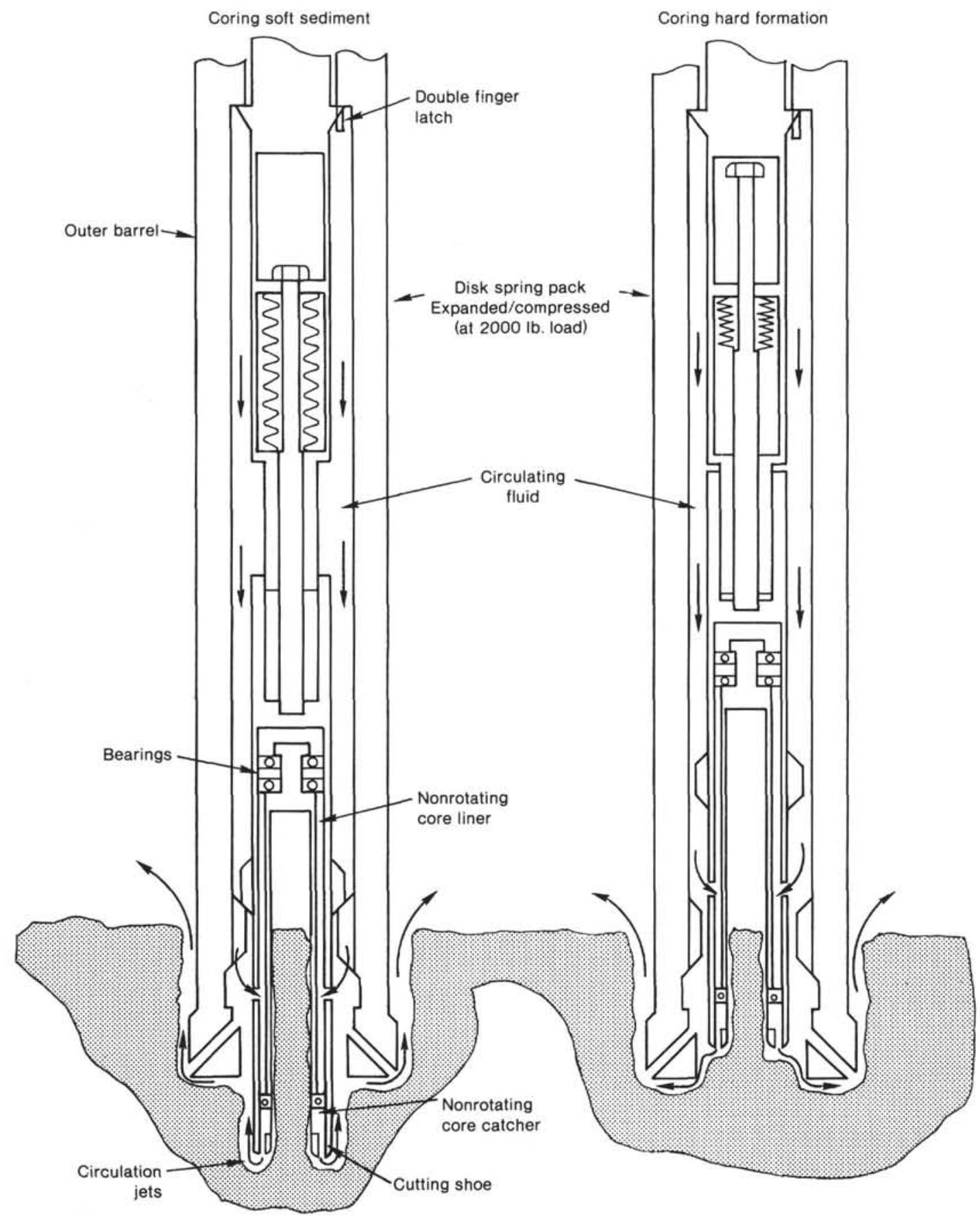

Figure 4. The Extended Core Barrel (XCB) was used during drilling operations on Leg 93. In soft sediments, the XCB extends ahead of the rotary drill bit, to recover less-disturbed sediment cores in the nonrotating core liner, thus avoiding much of the disturbance common in cores obtained by rotary drilling. In harder formations, the disk spring pack of the XCB is compressed so the cutting shoe is housed within the rotary drill bit, avoiding damage to the XCB cutting shoe during rotary coring operations.

the third hole drilled at Site 603 during Leg 93. A sample from the core catcher of this core might be designated "93-603B-77,CC (10-12 cm)."

The depth below the seafloor for a sample numbered "93-603B-77-4, 98-102 cm" is the sum of (1) the depth to the top of the cored interval for Core $77(1521.1 \mathrm{~m})$; (2) the depth to the top of the right section $(4.5 \mathrm{~m}$, to account for Sections 1-3); and (3) the depth below the top of the right section $(98 \mathrm{~cm})$. The sample in question is located at $1526.58 \mathrm{~m}$ sub-bottom, which in principle is the sample depth below the seafloor, disregarding complications caused by nonvertical DSDP holes (e.g., in Hole 603B, the deviation for this core was measured at $15^{\circ}$ from the vertical). Sample requests should refer to a specific interval within a core section, and not to the depth below seafloor. 
Table 2. Wash cores obtained by Leg 93 drilling.

\begin{tabular}{lrrr}
\hline & & & \\
Hole & Core & $\begin{array}{c}\text { Washed interval } \\
\text { (m sub-bottom) }\end{array}$ & $\begin{array}{c}\text { Sediment } \\
\text { recovered } \\
(\mathrm{m})\end{array}$ \\
\hline 603 & $2 \mathrm{M}$ & $9.0-83.8$ & 7.00 \\
603 & $3 \mathrm{M}$ & $83.8-122.2$ & 0.38 \\
603 & $5 \mathrm{M}$ & $131.8-170.2$ & 5.79 \\
603 & $7 \mathrm{M}$ & $179.8-199.0$ & 9.63 \\
603 & $11 \mathrm{M}$ & $227.8-266.2$ & 7.24 \\
603 & $13 \mathrm{M}$ & $275.8-314.2$ & 9.35 \\
603 & $15 \mathrm{M}$ & $323.8-362.2$ & 9.64 \\
603 & $17 \mathrm{M}$ & $371.8-410.2$ & 9.48 \\
603 & $19 \mathrm{M}$ & $419.8-448.6$ & 9.64 \\
603 & $22 \mathrm{M}$ & $467.8-506.2$ & 9.61 \\
603 & $24 \mathrm{M}$ & $515.8-544.6$ & 9.60 \\
603 & $28 \mathrm{M}$ & $563.8-573.4$ & 0.48 \\
603 & $53 \mathrm{M}$ & $803.8-823.0$ & 2.20 \\
$603 \mathrm{~B}$ & $1 \mathrm{M}$ & $0.0-285.0$ & 8.94 \\
$603 \mathrm{~B}$ & $2 \mathrm{M}$ & $285.0-417.1$ & 3.02 \\
$603 \mathrm{~B}$ & $3 \mathrm{M}$ & $417.1-479.0$ & 1.13 \\
$603 \mathrm{~B}$ & $4 \mathrm{M}$ & $532.1-638.3$ & 9.28 \\
$603 \mathrm{~B}$ & $6 \mathrm{M}$ & $831.0-850.2$ & 6.81 \\
$603 \mathrm{~B}$ & $7 \mathrm{M}$ & $850.2-869.4$ & 9.66 \\
$603 \mathrm{~B}$ & $8 \mathrm{M}$ & $869.4-892.0$ & 9.63 \\
$603 \mathrm{~B}$ & $11 \mathrm{M}$ & $907.8-927.0$ & 9.64 \\
$604 \mathrm{~A}$ & $1 \mathrm{M}$ & $0.0-249.6$ & 6.14 \\
605 & $1 \mathrm{M}$ & $0.0-154.3$ & 9.21 \\
\hline & & & \\
\hline
\end{tabular}

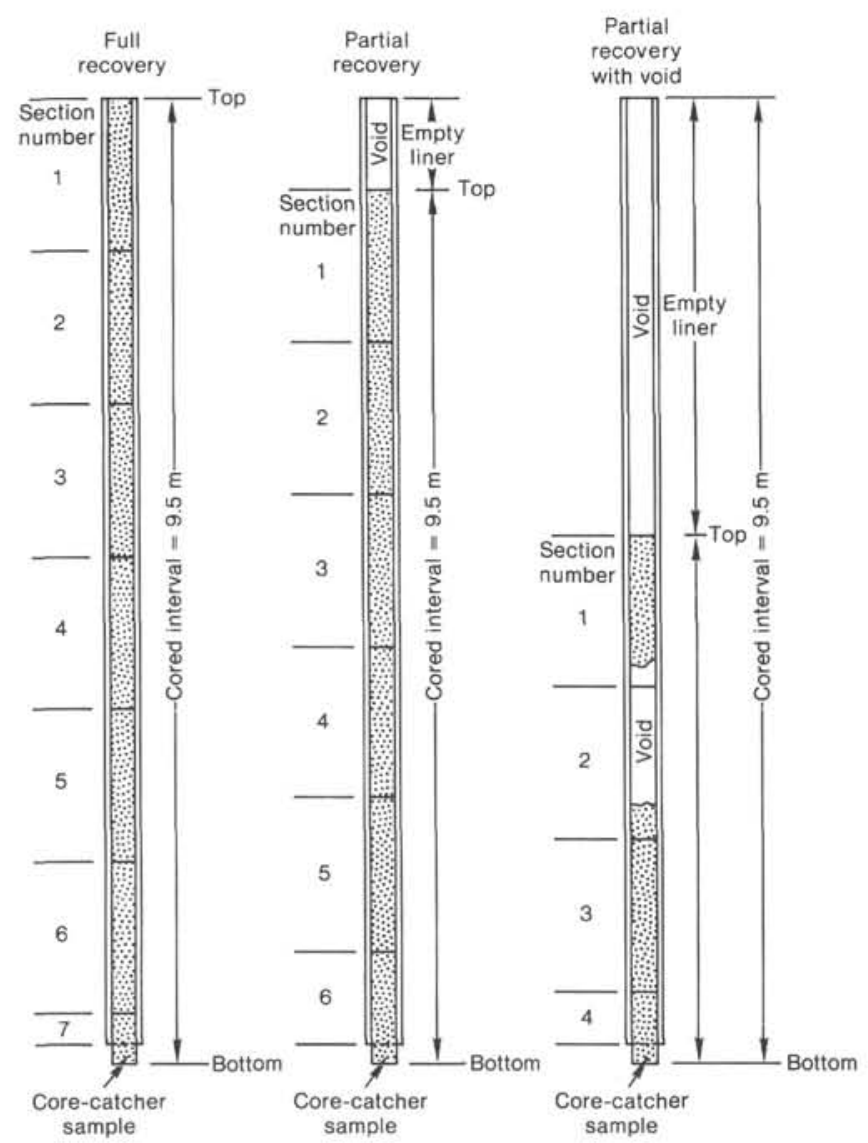

Figure 5. Diagram showing procedure in cutting and labeling of DSDP core sections.
Conventions regarding the cataloging of cores recovered by the hydraulic piston corer (HPC) or the extended core barrel (XCB) are the same as those for rotary cores.

\section{Handling of Cores}

A core is normally cut into $1.5 \mathrm{~m}$ sections, sealed, and labeled on the rig floor; the sections are then brought into the core laboratory for processing. The following determinations are normally made before the sections are split: gas analysis, thermal-conductivity analysis (soft sediment only), and continuous wet-bulk density determinations using the Gamma Ray Attenuation Porosity Evaluator (GRAPE).

A number of special samples were taken from Leg 93 cores for the study of their interstitial water (IW), physical properties (PP), and organic geochemistry $(\mathrm{OG})$. These were taken as whole-round samples (i.e., both the archive half and the work half of the core were removed), in limited quantities according to DSDP sampling policies. Leg 93 special samples are listed in Table 3, and also on the respective core-barrel sheets for each site. The interstitial water sediment samples were processed on board (see geochemistry section of the site chapters) for subsequent shore-based analyses. Physical properties samples were analyzed at Texas A\&M University and at the Open University (Biart, this volume). Organic geochemistry samples were frozen immediately aboard ship, and kept frozen until they were transferred to the DSDP West Coast repository for storage and postcruise sampling by interested geochemists.

The cores are then split longitudinally into working and archive halves, either by wire cutter or by "super saw." The contrast in appearance between cores cut by the two methods can be significant. Samples extracted from the working half include those for measurement of sonic velocity by the Hamilton Frame method, measurement of wet-bulk density by a GRAPE technique, carbon-carbonate analysis, measurement of carbonate percentage (carbonate bomb), geochemical analysis, paleontologic studies, and other studies. Smear slides (or thin sections for lithified sedimentary and igneous rocks) from each major lithology and most minor lithologies are prepared and examined by petrographic microscope. The archive half is then described and photographed. If sufficiently firm, it is washed on the cut surface to emphasize the sedimentary features. Physical disturbance by the drill bit, and the color, texture, structure, and composition of the various lithologies within a section are described on standard visual-core-description sheets (one per core), and any unusual features are noted.

After the cores are sampled and described, they are maintained in cold storage aboard the Glomar Challenger until they can be transferred to the repositories. All Leg 93 cores are presently stored at the East Coast Repository (Lamont-Doherty Geological Observatory, Columbia University), and frozen OG samples are presently stored at the West Coast Repository (Scripps Institution of Oceanography). 
Table 3. Leg 93 interstitial water (IW), organic geochemistry (OG), and physical properties (PP) samples.

\begin{tabular}{|c|c|c|c|c|c|}
\hline $\begin{array}{l}\text { Sample } \\
\text { type }\end{array}$ & Hole & $\begin{array}{l}\text { Core-Section } \\
\text { (interval in } \mathrm{cm} \text { ) }\end{array}$ & $\begin{array}{c}\text { Sample } \\
\text { type }\end{array}$ & Hole & $\begin{array}{l}\text { Core-Section } \\
\text { (interval in } \mathrm{cm} \text { ) }\end{array}$ \\
\hline IW & 603 & $9-3,140-150$ & PP & $603 \mathrm{C}$ & $6-5,140-150$ \\
\hline IW & 603 & $12-2,140-150$ & PP & $603 \mathrm{C}$ & $8-3,140-150$ \\
\hline IW & 603 & $14-3,140-150$ & PP & $603 C$ & $10-4,140-150$ \\
\hline IW & 603 & $16-4,140-150$ & PP & $603 C$ & $13-1,140-150$ \\
\hline IW & 603 & $20-4,140-150$ & PP & 604 & $1-3,140-150$ \\
\hline IW & 603 & $26-4,140-150$ & OG & 603 & $8-2,120-150$ \\
\hline IW & 603 & $31-1,140-150$ & OG & 603 & $12-2,110-140$ \\
\hline IW & 603 & $36-3,140-150$ & OG & 603 & $14-2,120-150$ \\
\hline IW & 603 & $39-1,140-150$ & OG & 603 & $21-3,120-150$ \\
\hline IW & 603 & $44-3,140-150$ & OG & 603 & $23-4,120-150$ \\
\hline IW & 603 & $52-4,140-150$ & OG & 603 & $25-4,120-150$ \\
\hline IW & $603 \mathrm{~B}$ & $10-3,140-150$ & OG & 603 & $30-4,120-150$ \\
\hline IW & $603 \mathrm{~B}$ & $13-1,140-150$ & OG & 603 & $34-3,120-150$ \\
\hline IW & $603 \mathrm{~B}$ & $18-3,140-150$ & OG & 603 & $38-2,120-150$ \\
\hline IW & 603B & $23-1,140-150$ & OG & 603 & $42-3,120-150$ \\
\hline IW & $603 \mathrm{~B}$ & $28-2,140-150$ & OG & 603 & $49-2,120-150$ \\
\hline IW & 603B & $34-4,140-150$ & OG & $603 \mathrm{~B}$ & $7-5,120-150$ \\
\hline IW & $603 \mathrm{~B}$ & $39-4,140-150$ & OG & $603 \mathrm{~B}$ & $12-2,120-150$ \\
\hline IW & $603 \mathrm{~B}$ & $44-3,140-150$ & OG & $603 \mathrm{~B}$ & $17-4,120-150$ \\
\hline IW & $603 \mathrm{~B}$ & $49-4,140-150$ & OG & $603 \mathrm{~B}$ & $22-3,120-150$ \\
\hline IW & $603 \mathrm{~B}$ & $52-5,140-150$ & OG & $603 \mathrm{~B}$ & $29-3,120-150$ \\
\hline IW & 503B & $58-3,140-150$ & OG & $603 \mathrm{~B}$ & $33-2,120-150$ \\
\hline IW & 503B & $64-4,140-150$ & OG & $603 \mathrm{~B}$ & $38-3,120-150$ \\
\hline IW & $503 \mathrm{~B}$ & $70-4,140-150$ & OG & $603 \mathrm{~B}$ & $43-4,0-30$ \\
\hline IW & $603 \mathrm{~B}$ & $75-2,140-150$ & OG & $603 \mathrm{~B}$ & $53-4,120-150$ \\
\hline IW & $603 \mathrm{~B}$ & $80-4,140-150$ & OG & $603 \mathrm{~B}$ & $59-4,120-150$ \\
\hline IW & $603 \mathrm{C}$ & $2-7,0-10$ & OG & $603 \mathrm{~B}$ & $66-2,120-150$ \\
\hline IW & $603 C$ & $3-4,118-123$ & OG & $603 \mathrm{~B}$ & $71-5,120-150$ \\
\hline IW & $603 \mathrm{C}$ & $4-6,140-150$ & OG & $603 \mathrm{~B}$ & $76-3,120-150$ \\
\hline IW & $603 \mathrm{C}$ & $5-4,140-150$ & OG & $603 \mathrm{~B}$ & $81-3,120-150$ \\
\hline IW & $603 C$ & $6-4,140-150$ & OG & $603 C$ & $4-5,120-150$ \\
\hline IW & $603 C$ & $7-4,140-150$ & OG & $603 C$ & $7-5,120-150$ \\
\hline IW & $603 C$ & $8-4,140-150$ & OG & $603 \mathrm{C}$ & $11-3,120-150$ \\
\hline IW & $603 \mathrm{C}$ & $9-6,140-150$ & OG & $603 C$ & $18-5,120-150$ \\
\hline IW & $603 \mathrm{C}$ & $10-3,145-150$ & OG & $603 \mathrm{C}$ & $21-3,120-150$ \\
\hline IW & $603 C$ & $11-4,134-144$ & OG & $603 \mathrm{C}$ & $27-5,120-150$ \\
\hline IW & $603 C$ & $13-1,130-140$ & OG & $603 \mathrm{C}$ & $33-5,120-150$ \\
\hline IW & $603 C$ & $15-5,140-150$ & OG & $603 \mathrm{C}$ & $37-5,120-150$ \\
\hline IW & $603 \mathrm{C}$ & $20-5,140-150$ & OG & 604 & $6-4,120-150$ \\
\hline IW & $603 \mathrm{C}$ & $25-5,140-150$ & OG & 604 & $11-4,120-150$ \\
\hline IW & $603 \mathrm{C}$ & $30-1,140-150$ & OG & 604 & $16-3,120-150$ \\
\hline IW & $603 C$ & $36-3,140-150$ & OG & 604 & $21-3,120-150$ \\
\hline IW & $603 C$ & $39-5,140-150$ & OG & 604 & $26-1,120-150$ \\
\hline IW & 604 & $5-1,140-150$ & OG & 604 & $27-1,120-150$ \\
\hline IW & 604 & $8-2,0-10$ & OG & 605 & $7-5,120-150$ \\
\hline IW & 604 & $13-3,140-150$ & OG & 605 & $11-5,120-150$ \\
\hline IW & 604 & $17-3,140-150$ & OG & 605 & $16-5,120-150$ \\
\hline IW & 604 & $22-5,140-150$ & OG & 605 & $21-4,120-150$ \\
\hline IW & 605 & $3-2,143-150$ & OG & 605 & $27-5,120-150$ \\
\hline IW & 605 & $9-4,140-150$ & OG & 605 & $33-2,120-150$ \\
\hline IW & 605 & $14-5,140-150$ & OG & 605 & $39-5,120-150$ \\
\hline IW & 605 & $19-5,140-150$ & OG & 605 & $44-4,120-150$ \\
\hline IW & 605 & $24-6,140-150$ & OG & 605 & $49-5,120-150$ \\
\hline PP & 603 & $4-7,25-35$ & OG & 605 & $56-3,120-150$ \\
\hline PP & 603 & $12-3,110-120$ & OG & 605 & $63-5,120-150$ \\
\hline PP & 603 & $14-4,140-150$ & OG & 605 & $69-3,120-150$ \\
\hline PP & $603 \mathrm{C}$ & $3-4,140-150$ & & & \\
\hline
\end{tabular}

\section{SEDIMENTS AND SEDIMENTARY ROCKS}

\section{Core Description Forms}

Visual core descriptions, smear-slide and thin-section descriptions, carbonate-bomb (percent $\mathrm{CaCO}_{3}$ ) determinations, and biostratigraphy (all done aboard ship) provide the data for the core descriptions in this volume. This information is summarized, and sample locations in the core are indicated on the core description sheets (Fig. 6). For all sites, information on the core descrip- tion sheets represents field notes taken aboard ship under time pressure. Some of this information has been refined in accordance with post-cruise findings, but production schedules prohibit definitive correlation of the core description sheets with subsequent findings, so occasional ambiguities or discrepancies may be present.

\section{Drilling Disturbance}

Recovered rocks, particularly soft sediments, may be extremely disturbed. This mechanical disturbance is the result of the coring technique, which uses a bit $25 \mathrm{~cm}$ in diameter with a $6-\mathrm{cm}$ diameter opening for the core sample. The HPC and the XCB were developed in an attempt to minimize drilling disturbance. The core description form (Fig. 6) contains a column in which drilling disturbance of recovered material is indicated. Blank regions indicate a lack of drilling disturbance. Symbols used by Leg 93 sedimentologists for four disturbance categories for soft sediments and four for firm sediments and sedimentary rocks are shown in Figure 7. The disturbance categories are defined as (1) slightly deformed: bedding contacts are slightly bent, (2) moderately deformed: bedding contacts have undergone extreme bowing, and firm sediment is fractured; (3) very deformed: bedding is completely disturbed or homogenized by drilling, sometimes showing symmetrical diapirlike structure; (4) soupy: water-saturated intervals have lost all aspects of original bedding; (5) slightly fractured: firm sediments are broken into pieces, but in stratigraphic sequence, with very little drilling slurry; (6) moderately fractured: broken pieces are in place or partly displaced, but their original orientation is preserved or recognized; (7) highly fragmented: broken pieces are present from the interval cored and are probably in the correct stratigraphic sequence (although they may not represent the entire section), but their original orientation has been lost; (8) drilling breccia: the firm pieces recovered have completely lost their original orientation and stratigraphic position, and may be mixed with drilling slurry.

\section{Sedimentary Structures}

In the soft, and even in some harder sedimentary cores, it may be extremely difficult to distinguish between natural structures and structures created by the coring process, and in these instances the description of sedimentary structures is optional. Locations and types of structures appear as graphic symbols in the "Sedimentary Structures" column on the core description form (Fig. 6). Figure 8 gives the key for these symbols.

Distinct burrows are noted by a symbol (Fig. 8) in the sedimentary structures column, and the extent of bioturbation, where distinguishable, is also noted in this column.

\section{Color}

Colors of the core samples are determined and indicated by the appropriate color designator from either the Geological Society of America Rock-Color Chart or the Munsell Soil Color Charts. Colors were determined 
SITE HOLE CORE CORED INTERVAL

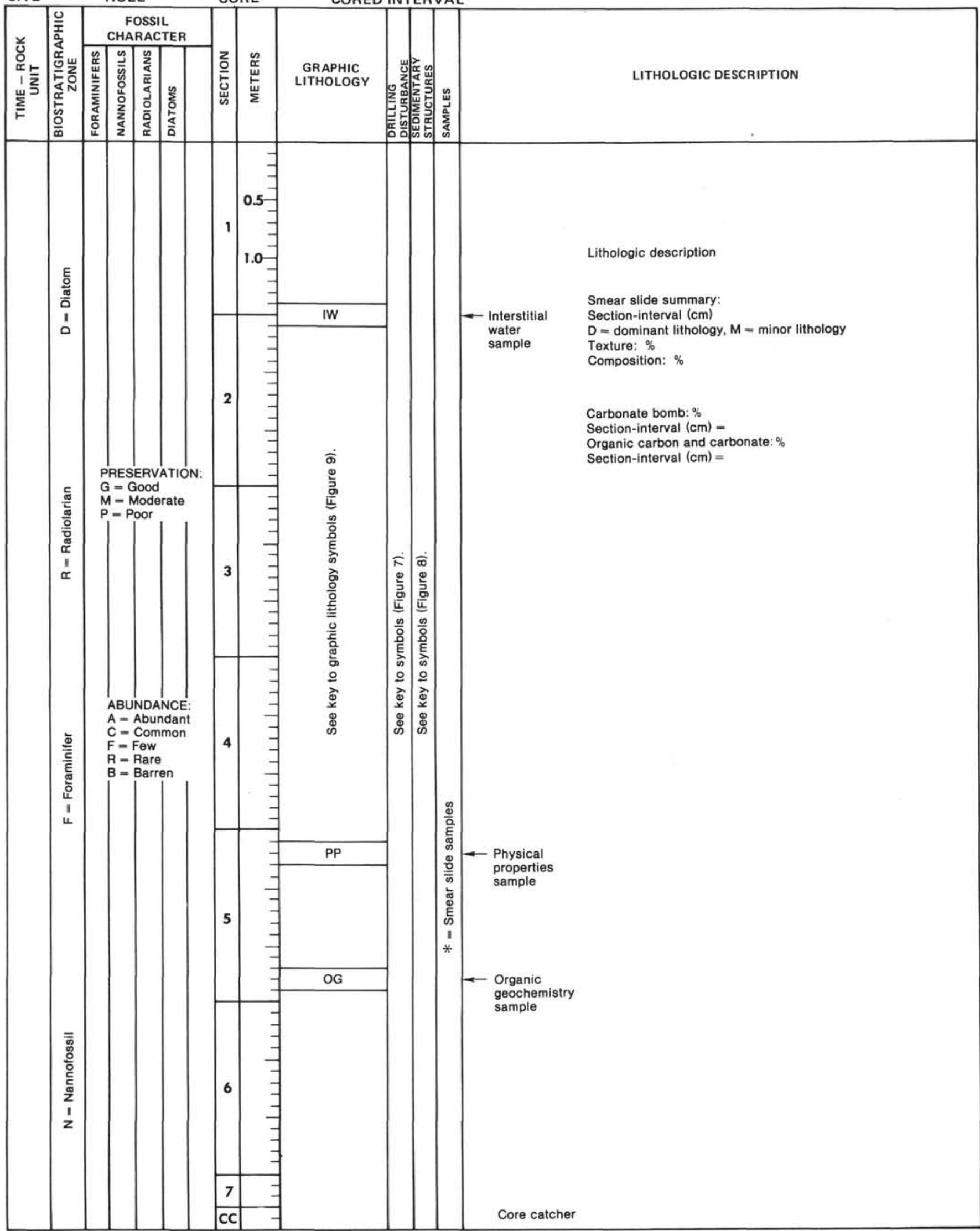

Figure 6. Sample core form for description of sediments (barrel sheet). 
Soft sediments

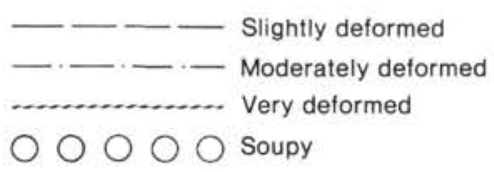

Hard sediments (from Benson, Sheridan, et al., 1978, pg. 18)
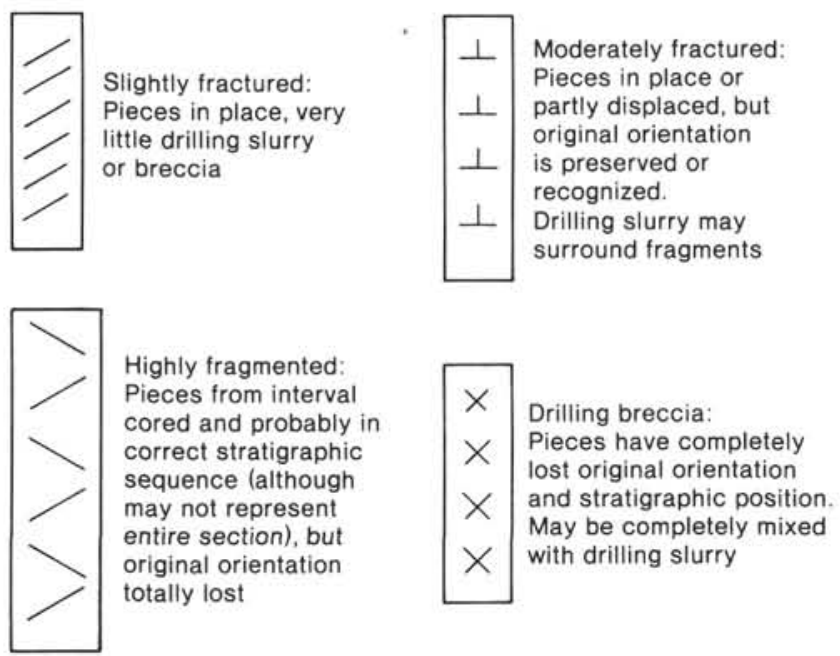

Figure 7. Leg 93 drilling disturbance symbols used on the core description forms.

immediately after the cores were split and while they were still wet, because certain colors in deep sea sediments are ephemeral (Moberly and Klein, 1976).

\section{Lithology}

The graphic column on the core description form is based on the lithologies, and the sediment is represented by a single pattern or by a grouping of two or more symbols (Fig. 9). The symbols in a grouping correspond to end-members of sediment compositional range, such as clay or nannofossil ooze. The terrigenous constituent is noted on the right, the biogenic constituent(s) on the left side of the column, in proportions approximately equal to their respective abundances in the sediment. For example, the left $20 \%$ of the column may have a diatom ooze symbol, whereas the right $80 \%$ may have a silty clay symbol, indicating sediment composed of $80 \%$ mud and $20 \%$ diatoms.

Because of the difference in the length-to-width ratio between the actual sediment core and the graphic lithology column, it is not possible to reproduce structures as they appeared in the core; in the graphic representation they are highly flattened and distorted. The same is true for rock fragments or pebbles in the cores. Thus the locations of pebbles are shown by a solid square, of concretions (e.g., pyrite nodules) by a circle surrounding the appropriate symbol. The depths of small minor lithologies (e.g., volcanic ash layers) are represented by a triangular inset of the appropriate lithologic symbol (Fig. 9) on the right side of the graphic lithology column (this convention applies to lithologies that do not extend across the entire core).

Because of the rapidly changing cyclic nature of certain lithologies in Leg 93 cores (e.g., Cretaceous marl-

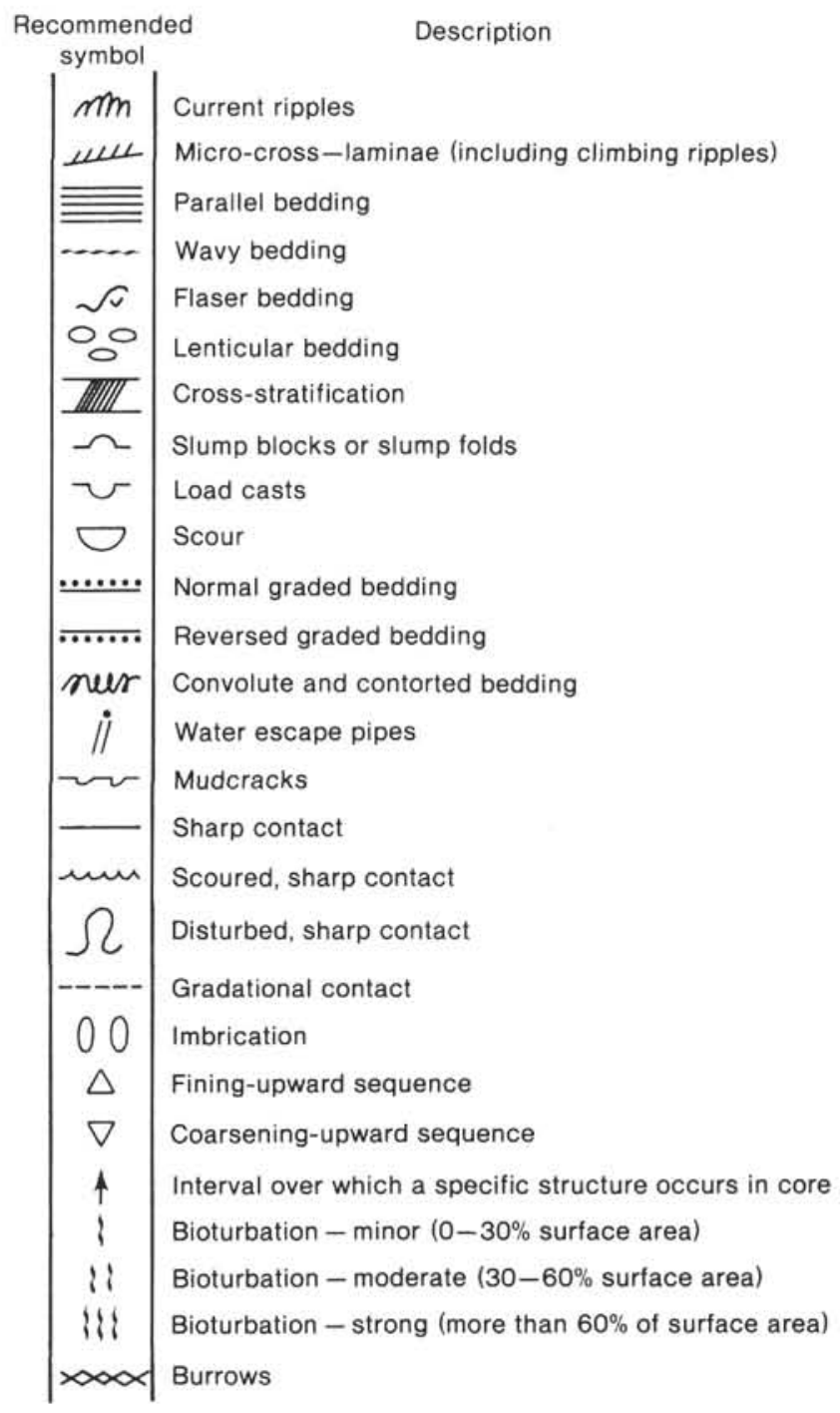

Figure 8. Symbols of sedimentary structures used on Leg 93 core description forms.

limestone cycles), it is impossible exactly to depict the detail of these cycles in the graphic lithology column. In these cases, the cyclic nature of the recovered material is graphically illustrated by a serrate pattern showing alternation of the two (or more) major lithologies in the core.

Format, style, and terminology of the descriptive portion of the core description forms (Fig. 6) are not controlled by the graphic lithology column, beyond the minimal name assignment which is derived from the lithologic classification (to be described).

Smear-slide (or thin-section) compositions, carbonate content (percent $\mathrm{CaCO}_{3}$ ) and organic carbon content determined on board are listed below the core description; the two numbers separated by a hyphen refer to the section and centimeter interval, respectively, of the sample. The locations of these samples in the core and a key to the codes used to identify them appear in the samples column (Fig. 6). The locations and intervals of the organic geochemistry, interstitial water, and physical property samples are given in both the samples and the graphic lithology columns, because removal of these 
Pelagic

Nonbiogenic

Pelagic clay

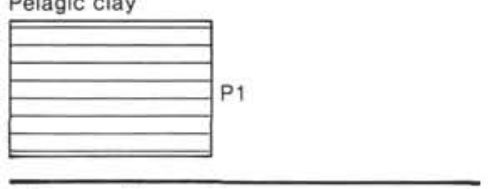

Siliceous biogenic

Pelagic siliceous biogenic - soft

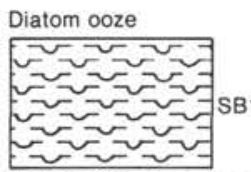

Pelagic siliceous biogenic

Diatomite

Radiolarian ooze

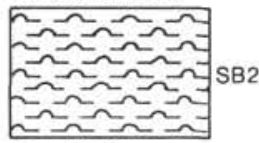

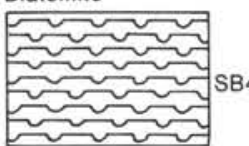

Vertical bar percent

(\%) designation for

graphic log

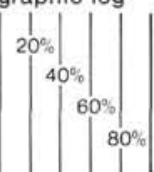

Diatom-radiolarian

or siliceous ooze

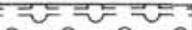

$\tilde{c}=\tilde{c}=0$

$\Omega=\Omega==$ SSB

$\Omega=\Omega=0$

Porcellanite Chert

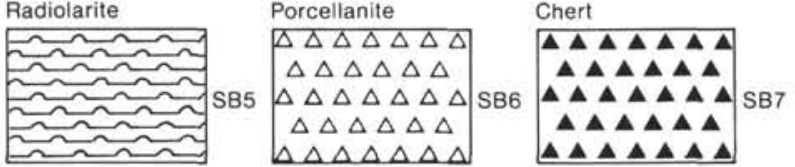

Calcareous biogenic

Pelagic biogenic calcareous - soft

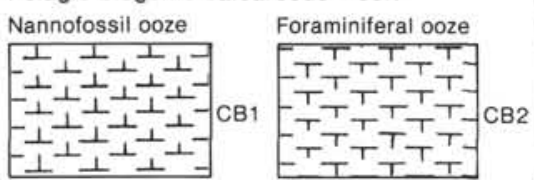

Pelagic biogenic calcareous - firm

Cannofossil chalk

Pelagic biogenic calcareous - hard

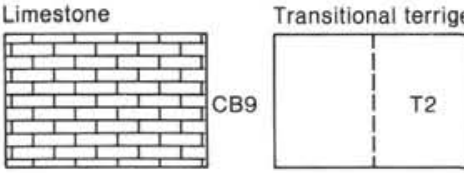

Nanno-foram or

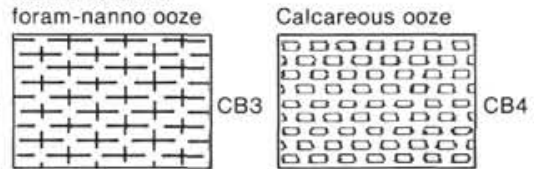

Nanno-foram or

foram-nanno chalk Calcareous chalk

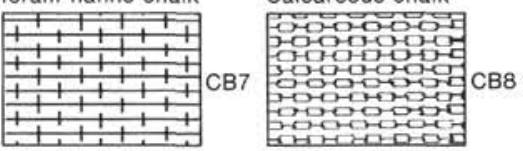

\section{Terrigenous sediments}

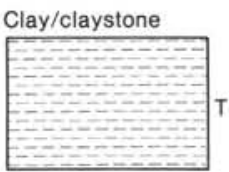

Silty sand/

sandy silt

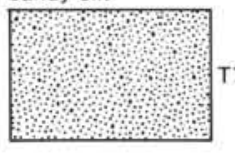

Special rock types biogenic modifier with area
approximate according to abundance

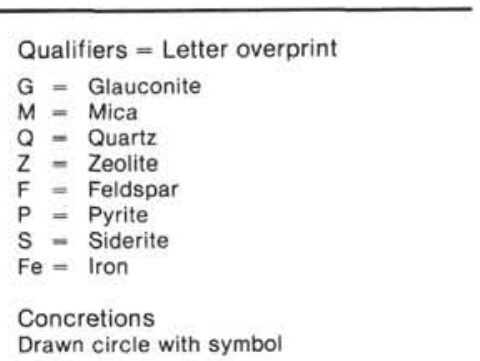

Qualifiers $=$ Letter overprint

$\mathrm{G}=$ Glauconite

$M=$ Mica

Q = Quartz

Z = Zeolite

$\mathrm{F}=$ Feldspar

$P=$ Pyrite

$\mathrm{S}$ - Siderite

$\mathrm{Fe}=$ Iron

Concretions

Drawn circle with symbol 
samples depletes both the work and the archive half of the core.

\section{LITHOLOGIC CLASSIFICATION}

The sediment classification scheme used on Leg 93 differs from that recommended by the JOIDES Panel on Sedimentary Petrology and Physical Properties (SPPP) in its use of compositional qualifiers for naming intermediate mixtures containing nonbiogenic and/or biogenic components. (For the original SPPP classification, see Ross, Neprochnov, et al., 1978, pp. 13-15). As a first approximation, we considered each sediment to be a mixture of nonbiogenic, siliceous biogenic, and calcareous biogenic components.

The Leg 93 classification is descriptive rather than generic, and lithologies are classified by their composition and texture. For example, in our classification, the term clay is used for clay minerals or terrigenous material less than $4 \mu \mathrm{m}$ in size without regard to origin; consequently the terms "hemipelagic" or "pelagic" clay do not appear in this classification. The Leg 93 classification follows the SPPP convention of using only terrigenous sedimentary components to classify a silt or clay. Therefore, the term "silt" or "silty" does not reflect the overall texture of the sediment including the biogenic components; for example, nannofossils as silt-size biogenic grains do not yield a sediment name of "nannofossil silt." The shipboard sedimentologists chose to use this new classification in order to (1) maintain an internal consistency in the naming of intermediate mixtures of nonbiogenic and/or biogenic components, and (2) provide simple descriptive qualifiers that indicate the important components and their abundance in the sediment.

\section{Composition and Texture}

In this classification, composition and texture are the only criteria used to define the type of sediment or sedimentary rock. Composition is more important for describing sediments deposited in the open ocean, and texture becomes significant for hemipelagic and nearshore sediments. These data come principally from visual analyses of smear slides with a petrographic microscope. They are estimates of abundance and size of the components on a slide and may differ somewhat from more accurate analyses of grain size, carbonate content, and mineralogy presented in related shore-based studies (this volume). Past experience indicates that quantitative estimates of distinctive minor components are accurate to within 1$2 \%$, but that accuracy for major constituents is poorer, $\pm 10 \%$. All smear-slide estimates were done on board.

\section{Rules for Classification Scheme}

1. $50 \%$ of a component or group of components (e.g., total biogenic silica or biogenic carbonate) determines the main name. Main names are:

(a) Nonbiogenic: If the total of a nonbiogenic component is greater than $50 \%$, the main name is determined by the dominant size(s) as defined in Shepard (1954; see Fig. 10), using the size classes defined by Wentworth (1922; see Fig. 11). Examples of nonbiogenic main names are clay, silt, silty clay, or sand. For grain size, sand-sized, silt-sized etc. may be added to the name.

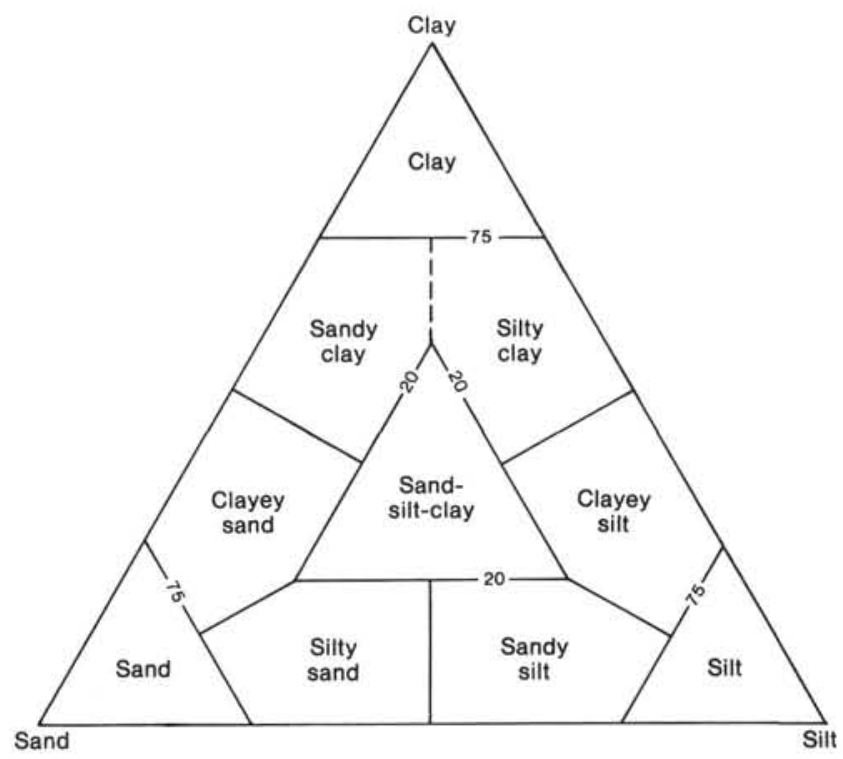

Figure 10. Sediment classification after Shepard (1954), with the sand-, silt-, and clay-sized fractions based on the Wentworth (1922) grade scale, consisting of sand-, silt-, and clay-sized particles having respective diameters of 2000 to $62.5 \mu \mathrm{m}, 62.5$ to $3.91 \mu \mathrm{m}$, and less than $3.91 \mu \mathrm{m}$. Shepard's (1954) sediment classification is a function of sand, silt, and clay size percentages and not of composition.

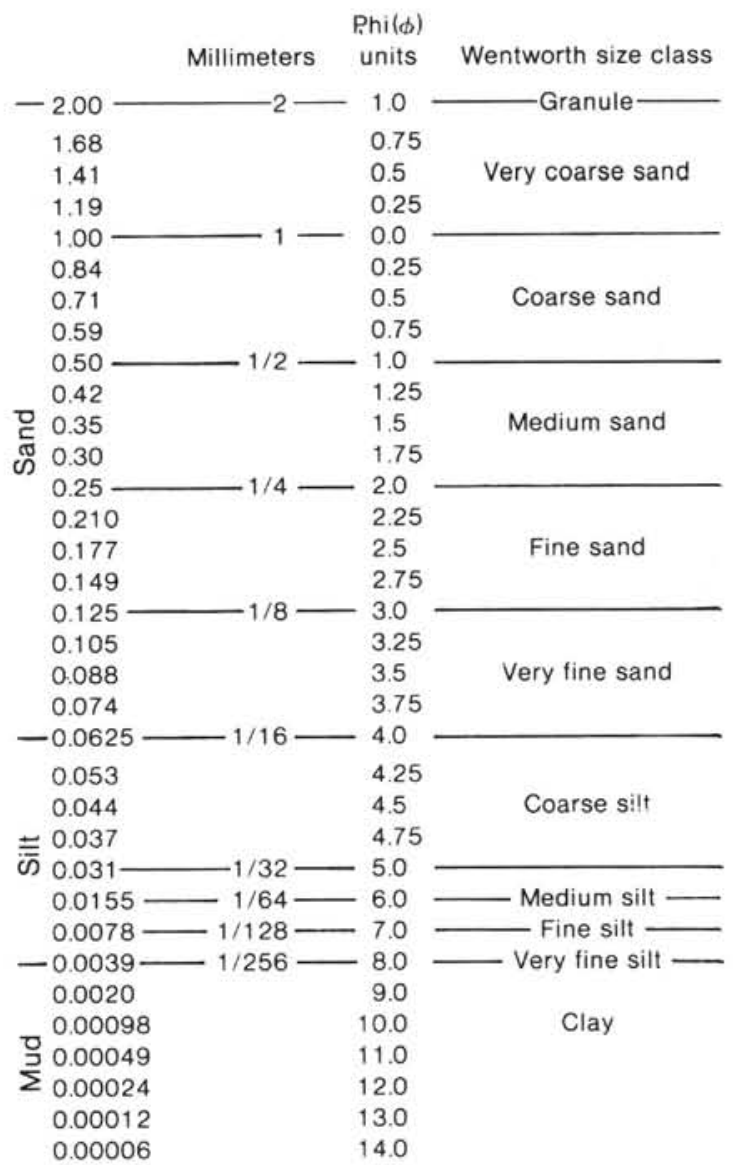

Figure 11. Grade scales for terrigenous sediments, after Wentworth (1922). 
(b) Biogenic: If the total of biogenic components is greater than $50 \%$, the main name is "ooze," or the appropriate term denoting sediment induration (see below).

2. $30-50 \%$ of a component qualifies for major-modifier status. Major modifiers are:

(a) Nonbiogenic: silty, clayey, sandy, etc.

(b) Biogenic carbonate: nannofossil, foraminifer, or calcareous (should be specific when possible).

(c) Biogenic silica: diatom, radiolarian, or siliceous biogenic (should be specific when possible).

3. $10-30 \%$ of a component qualifies for minor-modifier status and is hyphenated with the word "rich." Example: nannofossil-rich clay.

4. 2-10\% of an unusual, important component (e.g., zeolite, organic carbon, dolomite, quartz) also qualifies for minor-modifier status, but is hyphenated with the word "bearing." Example: zeolite-bearing clay.

5. The most abundant component appears closest to the main name. Major and minor modifiers are listed in order of decreasing abundance to the left of the main name.

Example: zeolite-bearing foraminifer-rich nannofossil clay.

$$
\begin{array}{llll}
(5 \%) & (15 \%) & (30 \%) & (50 \%)
\end{array}
$$

6. Marl was defined as $30-60 \% \mathrm{CaCO}_{3}$, the rest mostly clay; mud as terrigenous or hemipelagic clay-sized sediment.

\section{Induration of Sediments}

For calcareous sediments and sedimentary rocks, we recognize three classes of induration or lithification, after the method of Gealy et al. (1971): (1) soft = ooze; has little strength and is readily deformed under pressure of finger or broad blade of spatula; (2) firm = chalk; partially lithified, readily scratched with fingernail or edge of spatula; (3) hard = limestone, dolostone; well lithified and cemented, resistant or impossible to scratch with fingernail or edge of spatula.

No such scale exists for siliceous biogenic sediments and sedimentary rocks, although there is a continuum between soft siliceous oozes, firm diatomites and radiolarites, and hard porcellanites and cherts. Leg 93 sedimentologists used a two-step classification scheme for siliceous biogenic sediments: (1) soft $=$ ooze; sediment core may be split with wire cutter; (2) hard = porcellanite or chert; core must be cut by a diamond saw rather than a wire in the shipboard core splitting process. Porcellanite is usually dull, brown to white, fairly porous, and contains clay, zeolites, or carbonate. Chert, in contrast, is lustrous, has conchoidal fracture, and is much denser and harder than porcellanite. These two siliceous rock types usually can be readily distinguished in hand specimen and are sufficient for shipboard descriptions. More detailed descriptions require detailed studies involving thin sections, scanning electron microscopy, Xray diffraction, and chemical analyses (e.g., Heath and Moberly, 1971; Lancelot, 1973; Kastner et al., 1977; von Rad et al., 1978).

For nonbiogenic sediments, the SPPP classification was used, so the suffix "-stone" was added to the main sediment name if the core was sufficiently indurated that it had to be cut by the diamond saw in the shipboard core-splitting process.

\section{Special Rock Types}

The definition and nomenclature of sediment and rock types not included in the system described above are left to the discretion of shipboard scientists, with the recommendation that they adhere as closely as is practical to conventional terminology. Special rock categories used on Leg 93 include Conglomerates, Drilling Breccia, and Dolomite (Fig. 9).

Additionally, letter overprints were used on the graphic lithology column of Leg 93 core description forms, to indicate the presence of unusual, important (2-10\%) components disseminated in the sediment or sedimentary rock. These unusual components included quartz, siderite, glauconite, mica, pyrite, and feldspar (Fig. 9). Sedimentary concretions (e.g., pyrite nodules and layers, manganese nodules) were indicated by a circle drawn around the appropriate letter symbol.

\section{SPECIAL STUDIES OF SEDIMENTS}

\section{Biostratigraphy}

\section{Foraminifers}

The Cenozoic planktonic foraminiferal zonation used on Leg 93 follows Blow (1969), Stainforth et al. (1975), Berggren (1973, 1977, 1983), and Kennett and Srinivasan (1983). The Cretaceous zonation is based on Bartenstein et al, (1957, 1966), Bartenstein and Bolli (1973), Moullade (1966, 1974, in press), Sigal (1977), van Hinte (1976), and Magniez-Jannin et al. (in press), plus regional studies in the western Atlantic by Luterbacher (1972, Leg 11), Gradstein (1978, Leg 44), and Moullade (1983, Leg 76).

\section{Foraminiferal Abundance and Preservation}

The term "abundance" was used in two different ways-first, for the abundance of foraminifers in the sediment, and second, for the relative abundance of a particular species in the assemblages in a residue.

For the first case (which was employed in the abundance boxes at the top of the biostratigraphic forms), terms were:

$\mathrm{A}=$ abundant (about $2 \mathrm{~cm}^{3}$ of dry, foraminifer residue from $10 \mathrm{~cm}^{3}$ of a sediment or rock sample)

$\mathrm{C}=$ common (about $1 \mathrm{~cm}^{3}$, as just described)

$\mathrm{F}=$ few (about $0.5 \mathrm{~cm}^{3}$ )

$\mathrm{R}=\operatorname{rare}\left(0.2 \mathrm{~cm}^{3}\right.$ or less $)$.

For the second case, the terminology employed was:

$\mathrm{A}=$ over $30 \%$ of the foraminifer population of a residue

$\mathrm{C}=15-30 \%$

$\mathrm{F}=3-15 \%$

$\mathrm{R}=<3 \%$.

Percentages were estimated by visual examination.

Preservation included, in this case, the effect of dissolution on abundance and diversity of residues as well as on the condition of individual tests. 


$$
\begin{aligned}
\mathrm{G}= & \text { good (dissolution effects rare and obscure) } \\
\mathrm{M}= & \text { moderate (specimen dissolution common but } \\
& \text { minor; specimens are typically few or, at best, } \\
& \text { common; and diversity is noticeably reduced, } \\
& \text { such as } 10 \text { species or less) } \\
\mathrm{P}= & \text { poor (specimens are small, compact, thick- } \\
& \text { walled, mineral-filled, and encrusted or various- } \\
& \text { ly perforated; } 1-6 \text { species). }
\end{aligned}
$$

\section{Nannofossils}

The calcareous nannofossil zonation used by Leg 93 biostratigraphers is basically that of Bukry $(1973,1975)$ for the Cenozoic, incorporating the letter-number zonal designations of Okada and Bukry (1980). For Pleistocene sediments, the zonation of Gartner (1977) was utilized.

Cretaceous sediments were subdivided using the zonations of Thierstein $(1971,1973)$ and Roth $(1973,1978$, 1983).

\section{Radiolarians}

The Cenozoic radiolarian zonation of Riedel and Sanfilippo (1971), incorporating the taxonomic revision of the cannartid-ommatartid lineages (Sanfilippo and Riedel, 1980), was used. Additional information for Cenozoic age assignments of Leg 93 sediments was provided by trissocyclid lineages listed in Goll (1968).

Cretaceous radiolarian assemblages were assigned ages based on the chronologies of Dumitricar (1970), Foreman (1975), Pessagno (1976, 1977), and Schaaf (1981).

\section{Shipboard Geochemical Measurements}

Shipboard geochemistry procedures included measurements of both organic and inorganic parameters of sediments and rocks from Leg 93. Primary geochemical objectives of this leg were to determine source characteristics and maturity of the organic matter contained in Cretaceous and Jurassic black shales. Secondary objectives were to determine interstitial gas compositions, including the possible existence of gas hydrates, and to investigate interstitial water chemistry. The procedures used to achieve these objectives were CHN analysis, RockEval pyrolysis, gas analyses, and ion analyses. In addition, calcium carbonate concentrations were routinely measured throughout the section.

\section{CHN Procedure}

Shipboard organic carbon analyses were done using a Hewlett-Packard 185-B CHN Analyzer. Portions of samples selected for calcium carbonate determinations were treated with dilute $\mathrm{HCl}$ to remove carbonate, washed with deionized water, and dried at $110^{\circ} \mathrm{C}$. A Cahn Electrobalance was used to weigh $20 \mathrm{mg}$ samples of sediment for $\mathrm{CHN}$ analysis. Samples were combusted at $1050^{\circ} \mathrm{C}$ in the presence of an oxidant, and the volumes of the evolved gases determined as measures of the $\mathrm{C}, \mathrm{H}$, and $\mathrm{N}$ contents of sediment organic matter. Areas of gas peaks were determined with a Columbia Scientific Industries integrator and compared to those of rock standards of known carbon and nitrogen contents (Shipboard Organic Geochemistry Manual). These values were used to standardize instrument response so the $\mathrm{C} / \mathrm{N}$ atomic ratios could be reported. This approach differs from earlier procedures, which used a synthetic $\mathrm{CHN}$ standard to determine nitrogen response factors. Hydrogen elemental analysis with the procedure used is untrustworthy because of the variable amounts of clay minerals and their hydrates; hence hydrogen values are not reported for samples analyzed by this method.

\section{Rock-Eval Procedure}

The source character and maturity of organic matter in selected rock samples were determined with the shipboard Girdel Rock-Eval pyrolysis instrument, which uses the Institut Français du Pétrole-FINA process described by Espitalié et al. (1977). About $100 \mathrm{mg}$ of coarsely ground, dry sample is heated from $250-550^{\circ} \mathrm{C}$ at a rate of $250^{\circ} \mathrm{C} / \mathrm{min}$. Gases released during the heating are carried off in a helium stream, which is split into two parts. One part is directed through a flame ionization detector to monitor hydrocarbons; the other passes through a $\mathrm{CO}_{2}$ trap, from which the total amount of evolved $\mathrm{CO}_{2}$ is released at the end of the heating program to be measured by a thermal conductivity detector.

This pyrolysis procedure yields four parameters which characterize the organic matter in a sample:

(1) Area of peak $S_{1}$, which corresponds to the quantity of hydrocarbons present in sample.

(2) Area of peak $\mathrm{S}_{2}$, which corresponds to the quantity of hydrocarbons released by pyrolysis of kerogen up to $550^{\circ} \mathrm{C}$, or the "hydrocarbon potential."

(3) Temperature, $T_{\max }$, of the top of peak $\mathrm{S}_{2}$, which is related to the maturity of the organic matter.

(4) Area of peak $\mathrm{S}_{3}$, which corresponds to the $\mathrm{CO}_{2}$ released from pyrolysis of kerogen.

From $\mathrm{S}_{1}$ and $\mathrm{S}_{2}$, the "hydrocarbon production index," or ratio of $S_{1} /\left(S_{1}+S_{2}\right)$, may be calculated. From $S_{2}, S_{3}$, and the organic carbon concentration, the hydrogen index (HI) and oxygen index (OI) can be calculated and used to determine kerogen source character and maturity.

\section{Gas Analysis Procedures}

The composition of gaseous hydrocarbons in the cores was investigated for two principal reasons. First, as a safety consideration, such monitoring is intended to ensure that no reservoir or accumulation of liquid or gaseous hydrocarbons is penetrated. Second, the downhole profile of hydrocarbon gases can provide evidence of microbial activity and/or diagenesis within the sedimentary column. In general, these compounds originate either directly from the activity of organisms (biogenic gases) or as products of thermal alteration of organic matter (diagenetic gases). The mutual ratios of several of these gases, such as methane/ethane, show trends that can reflect the increasing thermal maturity of the samples.

Gas samples were collected by piercing core liners with a needle that allowed gases to pass via stopcock into either a syringe or into a "vacutainer." Such sampling was performed as soon as each core was brought onto the deck. Where possible, samples were taken from gas pockets. Because contamination from the rubber stoppers of 
the "vacutainers" precluded analysis of hydrocarbons with GC retention times greater than that of pentane, use of a syringe was preferred.

Two gas chromatographs (GC) were used routinely for analysis of gaseous hydrocarbons; a Carle 8000 for methane and ethane and a Hewlett-Packard 5711A for ethane through pentane $\left(\mathrm{C}_{2}-\mathrm{C}_{5}\right.$ components). The Carle GC is equipped with a thermal conductivity detector and is fitted with a QS column, $1.5 \mathrm{~m} \times 3.1 \mathrm{~mm}$ outside diameter (OD) operated isothermally at $45^{\circ} \mathrm{C}$. Samples are injected directly into this column. The Hewlett-Packard GC had dual flame ionization detectors which are operated in the compensation mode. After injection, samples pass through in the helium gas flow, via a Carle 2014 microvolume sampling valve, to an alumina-filled loop $\left(20 \mathrm{~cm} \times 3.1 \mathrm{~m}\right.$ OD packed with $60 / 80$ mesh $\left.\mathrm{Al}_{2} \mathrm{O}_{3}\right)$ precooled to ca. $-70^{\circ} \mathrm{C}$ (refrigerated propan-2-ol bath). After $90 \mathrm{~s}$ (to allow methane stripping) the trapping loop is closed and heated for $60 \mathrm{~s}$ in a hot water bath $(90-$ $100^{\circ} \mathrm{C}$ ), before the sample is introduced into the GC column $(1.8 \mathrm{~m} \times 3.1 \mathrm{~mm}$ OD 40-100 mesh Spherosil linked to $3.6 \mathrm{~m} \times 3.1 \mathrm{~mm}$ OD $20 \%$ OV-101 on $100 / 110$ mesh Anakrom AS) by turning the sampling valve. The column is heated from $60-200^{\circ} \mathrm{C}$ at $8^{\circ} \mathrm{C} / \mathrm{min}$.

Mixtures of authentic $\mathrm{C}_{1}$ through $\mathrm{C}_{6}$ hydrocarbons (Scott mixtures 1, 2, 7, and 60) were used to provide retention times employed for gas identifications and to construct GC response plots for these light hydrocarbons.

\section{Interstitial Water Procedures}

Sediment samples were squeezed under 12 tons of pressure with hydraulic presses to force out interstitial water. The water samples were analyzed for $\mathrm{pH}$ and alkalinity with a Corning Model $130 \mathrm{pH}$ meter. Salinity was determined with an American Optical Company salinity refractometer, and chloride concentration measured by titration with silver nitrate. Wescan Ion Analyzers were used to measure concentrations of $\mathrm{Li}^{+}, \mathrm{K}^{+}, \mathrm{Ca}^{++}$, $\mathrm{Mg}^{++}$, and $\mathrm{SO}_{4}^{-}$in the samples of interstitial water.

\section{Calcium Carbonate Determinations}

Concentrations of calcium carbonate were determined by the "carbonate bomb" procedure of Müller and Gastner (1971), as revised by Dunn (1980). Dried samples of sediment and rock are ground, and $\sim 1 \mathrm{~g}$ is treated with $\mathrm{HCl}$ in a closed cylinder. The resulting increase in pressure caused by formation of $\mathrm{CO}_{2}$ gas is proportional to the concentration of $\mathrm{CaCO}_{3}$.

\section{Physical Properties}

Thorough discussion of measurement procedures for physical properties is found in Boyce $(1973,1976,1984)$, including descriptions of equipment, methods, errors, correction factors, and problems related to coring disturbance. On Leg 93, measurements were made of sonic velocity, vane shear strength, penetrometer strength, and wet-bulk density by the shipboard GRAPE. Gravimetric procedures were used to determine wet-bulk density, water content, porosity, and grain density, using either the chunk method (Boyce, 1973) or the cylinder method (Boyce, 1984).

\section{Sonic Velocity}

Compressional wave velocities were measured on the Hamilton Frame Velocimeter by timing a $400-\mathrm{kHz}$ pulse between two transducers and by measuring the distance across the sample with a dial gauge. Velocities in unconsolidated sediments were generally measured on the split core; correction factors established by Boyce (1976) were used to compensate for increased thickness and travel time caused by the polycarbonate liner $(0.242 \mathrm{~cm}$ and $1.108 \mu \mathrm{s}$ thick, respectively). For consolidated sediments, a piece was removed from the core and trimmed carefully to form two parallel surfaces to ensure good contact with the transducer heads. Salt water was used to make an acoustic contact between the sample and the transducers. On indurated sediments, measurements were made of both horizontal (perpendicular to the core axis) and vertical (parallel to the core axis) sonic velocities. By measuring aluminum, Lucite, and brass standards of known lengths and assumed velocities, correction factors were determined for the oscilloscope.

\section{Vane Shear and Penetrometer Strength}

A Soiltest Torvane and a CL-700 Soiltest Pocket Penetrometer were used on board to determine the shear strength and the penetrometer strength (unconfined compression strength) of Leg 93 sediments and sedimentary rocks. The Torvane blades were buried about $0.5 \mathrm{~cm}$ below the sediment surface of the split core halves, with the vane axis oriented parallel to the bedding plane of the sediment.

The Torvane is hand-rotated at a rate designed to reach failure in about $10 \mathrm{~s}$ with constant loading. Repeated determinations yielded results that were generally reproducible to $\pm 10 \%$. Measurements were made in the least disturbed sections of the split core, parallel to the core axis, and were discontinued when cracking of the sediments was observed, indicating failure by fracturing rather than by shear.

The Pocket Penetrometer was pushed into undisturbed sections of the split core from Holes 603C, 604, and 605 . These data give the compression strength parallel to bedding.

\section{GRAPE}

The Gamma Ray Attenuation and Porosity Evaluator (GRAPE) was used to determine wet-bulk density based on the attenuation of gamma rays by the sample. Boyce (1976) discusses the theoretical aspects in detail. During Leg 93, continuous GRAPE wet-bulk density determinations were made by irradiating the unsplit core sections. Although the Tektronix computer aboard ship failed, both analog and digitized graphs of GRAPE density data are now available.

Boyce (1976) estimates $\pm 5 \%$ accuracy for continuous GRAPE data, if the sediment completely fills the core liner. This was not the case for many Leg 93 cores, so the core photographs from each hole should be carefully examined before analyzing GRAPE data. In particular, many of the deeper cores from Hole 605 contained harder cores of reduced diameter, surrounded by 
finely ground particles of drill breccia (e.g., Core 60568 ), when worn bearings caused the cones in the drill bit to wobble.

\section{Gravimetric Procedures}

The methods used here are described by Boyce (1973, 1976, 1984). Wet-bulk density, grain density, porosity, and water content were all determined for the identical sample intervals for which sonic velocities were determined, generally at intervals of $1.5 \mathrm{~m}$ (one sample per core section). The cylinder technique (Boyce, 1984) was used on soft or stiff sediments. Samples were taken with stainless steel or brass cylinders of known volume and weight, and were tightly enclosed until they could be weighed. On indurated sediment and hard rock, the gravimetric chunk technique (Boyce, 1973) was used, in which samples cut out of the core for measurement of sonic velocities were stored under seawater. The volume of the chunk was determined by weighing it both in air and suspended under water.

Sample volume and weight yield the wet-bulk density without a buoyancy correction. Wet-water content and porosity were calculated from the water loss after drying at $110^{\circ} \mathrm{C}$ for $24 \mathrm{hr}$. Water content is related to the weight of the wet samples and therefore is defined here as wetwater content. All wet-water content and porosity data are corrected for salt content, using the correction factors for seawater (Boyce, 1976). The approximate grain density was calculated from the gravimetric data (as it is only an approximation, no correction for salt content was applied). The porosity is calculated assuming that the sediments are water-saturated. This may not be true of all samples, because some undergo adiabatic expansions if the in situ pressure is released when the cores are brought from the seafloor to the shipboard laboratory. The effect of an increase in the volume of the samples caused by elastic rebound after the removal of in situ overburden pressure (Hamilton, 1976), was not taken into account.

\section{Downhole Temperature}

The Uyeda temperature probe was used at Site 603, to measure downhole temperatures. The probe is lowered into the hole in place of the inner core barrel, and extends out through the drill bit into the sediments below. The top of the probe is inserted into the sediments in the bottom of the hole, and allowed about $20 \mathrm{~min}$. to approach an equilibrium temperature. The water temperature is also measured at the seafloor as the probe is retrieved after each run (the tool stops at about $20 \mathrm{~m}$ above the seafloor for $10 \mathrm{~min}$.). Thermistor accuracy is better than $0.1^{\circ} \mathrm{C}$. For a more complete description of this tool, see Becker, et al. (1983). Four temperature measurements were made in five attempts in Hole 603 (on the first attempt, the probe stuck in the BHA about $30 \mathrm{~m}$ above the bottom of the hole), and two additional measurements were made in Hole 603C. The downhole temperature results are discussed in the Physical Properties section of the Site 603 chapter.

\section{Photography}

As supplements to the core descriptions, sets of color slides and black and white photographs of whole cores are available for consultation at both core repositories. In addition, negatives in black and white for close-up documentation of special structures are archived at the Ocean Drilling Program, Texas A\&M University. Photographs are available on a charge and time available basis.

\section{REFERENCES}

Bartenstein, H., Bettenstaedt, F., and Bolli, H. M., 1957. Die Foraminiferen der Unterkreide von Trinidad, BWI-Cuche und Toco Formation. Eclogae Geol. Helv., 50:5-65.

1966. Die Foraminiferen der Unterkreide von Trinidad, W.I.,Maridale-Formation (Typlokalit). Eclogae Geol. Helv., 59:129-175.

Bartenstein, H., and Bolli, H. M., 1973. Die Foraminiferen der Unterkreide von Trinidad, W.I.-Maridale-Formation (Cotyplokalit). Eclogae Geol. Helv., 66:389-418.

Becker, K., Von Herzen, R. P., and Karato, S., 1983. Geothermal measurements from drilling of sediments near the Galapagos Spreading Center, $86^{\circ} \mathrm{W}$, Deep Sea Drilling Project Leg 70 . In Honnorez, J., Von Herzen, R. P., et al., Init. Repts. DSDP, 70: Washington (U.S. Govt. Printing Office), 445-458.

Benson, W. E., Sheridan, R. E. et al., Init. Repts. DSDP, 44: Washington (U.S. Govt. Printing Office).

Berggren, W. A., 1973. The Pliocene time-scale: calibration of planktonic foraminiferal and calcareous nannoplankton zones. Nature, 243(5407):391-397.

1977. Late Neogene planktonic foraminiferal biostratigraphy of the Rio Grande Rise (South Atlantic). Mar. Micropaleontol., 2:265-313.

1983. Neogene planktonic foraminiferal biostratigraphy and biogeography: Atlantic, Mediterranean and Indo-Pacific regions. In Tsuchi, R. (Ed.), Pacific Neogene and Datum Planes. Int. Geol. Correlation Progr. Proj. 114: Tokyo (University of Tokyo Press).

Blow, W. H., 1969. Late middle Eocene to Recent planktonic foraminiferal biostratigraphy. In Brönnimann, P., and Renz, H. H. (Eds.), Proc. First Int. Conf. Planktonic Microfossils (Vol. 1): Leiden (E. J. Brill), 199-241.

Boyce, R. E., 1973. Appendix I. Physical property methods. In Edgar, N. T., Saunders, J. B., et al., Init. Repts. DSDP, 15: Washington (U.S. Govt. Printing Office), 1115-1128.

1976. Definitions and laboratory techniques of compressional sound velocity parameters and wet-water content, wet-bulk density, and porosity parameters by gravimetric and gamma ray attenuation techniques. In Schlanger, S. O., Jackson, E. D., et al., Init. Repts. DSDP, 33: Washington (U.S. Govt. Printing Office), 931-958.

, 1984. Leg 75 methods for laboratory measured physical properties, Gearhart-Owen well logs, and the Uyeda downhole temperature probe. In Hay, W. W., Sibuet, J. D., et al., Init. Repts. DSDP, 75: Washington (U.S. Govt. Printing Office), 1179-1187.

Bukry, D., 1973. Low-latitude coccolith biostratigraphic zonation. In Edgar, N. T., Saunders, J. B., et al., Init. Repts. DSDP, 15: Washington (U.S. Govt. Printing Office), 685-703.

1975. Coccolith and silicoflagellate stratigraphy, northwestern Pacific Ocean, Deep Sea Drilling Project, Leg 32. In Larson, R. L., Moberly, R., et al., Init. Repts. DSDP, 32: Washington (U.S. Govt. Printing Office), 677-701.

Dumitrică, P., 1970. Cryptocephalic and cryptothoracic Nassellaria in some Mesozoic deposits of Romania. Rev. Roum. Geol., Geophys., Geogr., Ser. Geol., 14(1):45-124.

Dunn, D. A., 1980. Revised techniques for quantitative calcium carbonate analysis using the "Karbonate Bomb," and comparisons to other quantitative carbonate analysis methods. J. Sed. Petrol., 50: 631-637.

Espitalié, J., Madec, M., and Tissot, B., 1977. Source rock characterization method for petroleum exploration. Offshore Technology Conf. Proc., pp. 399-404. 
Foreman, H. P., 1975. Radiolaria from the North Pacific, Deep Sea Drilling Project, Leg 32. In Larson, R. L., Moberly, R., et al., Init. Repts. DSDP, 32: Washington (U.S. Govt. Printing Office), 579-676.

Gartner, S., 1977. Calcareous nannofossil biostratigraphy and revised zonation of the Pleistocene. Mar. Micropaleontol., 2:1-25.

Gealy, E. L., Winterer, E. L., and Moberly, R. M., Jr., 1971. Methods, conventions, and general observations. In Winterer, E. L., Riedel, W. R., et al., Init. Repts. DSDP, 7, Pt. 1: Washington (U.S. Govt. Printing Office), 9-26.

Goll, R. M., 1968. Classification and phylogeny of Cenozoic Trissocyclidae (Radiolaria) in the Pacific and Caribbean basins, Part I. J. Paleontol., 42:1409-1432.

Gradstein, F. M., 1978. Biostratigraphy of Lower Cretaceous Blake Nose and Blake-Bahama Basin Foraminifers, DSDP Leg 44, western North Atlantic Ocean. In Benson, W. E., Sheridan, R. E., et al., Init. Repts. DSDP, 44: Washington (U.S. Govt. Printing Office), 663-702.

Hamilton, E. L., 1976. Variations of density and porosity with depth in deep-sea sediments. J. Sed. Petrol., 46:280-300.

Heath, G. R., and Moberly, R., 1971. Cherts from the western Pacific, Leg 7, Deep Sea Drilling Project. In Winterer, E. L., Riedel, W. R., et al., Init. Repts. DSDP, 7, Pt. 2: Washington (U.S. Govt. Printing Office), 991-1007.

Kastner, M., Keene, J. B., and Gieskes, J. M., 1977. Diagenesis of siliceous oozes. I. Chemical controls on the rate of opal-A to opal-CT transformation-an experimental study. Geochim. Cosmochim. Acta, 41:1041-1059.

Kennett, J. P., and Srinivasan, M. S., 1983. Neogene Planktonic Foraminifera: A Phylogenetic Atlas: Stroudsburg, PA (Hutchinson \& Ross).

Klitgord, K. D., and Grow, J. A., 1980. Jurassic seismic stratigraphy and basement structure of the western Atlantic Magnetic Quiet Zone. Am. Assoc. Pet. Geol. Bull., 64:1658-1680.

Lancelot, Y., 1973. Chert and silica diagenesis in sediments from the central Pacific. In Winterer, E. L., Ewing, J. I., et al., Init. Repts. DSDP, 17: Washington (U.S. Govt. Printing Office), 377-405.

Luterbacher, H. P., 1972. Foraminifera from the Lower Cretaceous and Upper Jurassic of the northwestern Atlantic. In Hollister, C. D., Ewing, J. I., et al., Init. Repts. DSDP, 11: Washington (U.S. Govt. Printing Office), 561-593.

Magniez-Jannin, F., Moullade, M., and Tronchetti, G., in press. Biostratigraphie du Crétacé inférieur: repartition des foraminifères planctiques et benthiques en milieu de bassin. In Debrand-Passard, S., and Cotillon, P. (Eds.), Synthèse Géol. Vallée du Rhône (Bureau de Recherches Géologiques det Minières).

Matthews, D. J., 1939. Tables of the Velocity of Sound in Pore Water and in Seawater: London (Admiralty, Hydrographic Department).

Moberly, R., and Klein, G. de V., 1976. Ephemeral color in deep-sea cores. J. Sed. Petrol., 46:216-225.

Moullade, M., 1966. Etude stratigraphique et micropaléontologique du Crétacé inférieur de la "fosse vocontienne." Doc. Lab. Geol. Fac. Sci. Lyon, 15:1-369.

1974. Zones de foraminifères du Crétacé inférieur mesogéen. C. R. Acad. Sci., Ser. D, 14(278):1813-1816.

1983. Upper Neogene and Quaternary planktonic foraminifers from the Blake Outer Ridge and Blake-Bahama Basin (western North Atlantic), Deep Sea Drilling Project Leg 76, Sites 533 and 534. In Sheridan, R. E., Gradstein, F. M., et al., Init. Repts. $D S D P$, 76: Washington (U.S. Govt. Printing Office), 511-535.

, in press. Intérêt des petits foraminiferès "profonds" pour la biostratigraphie et l'analyse des paléoenvirononnements océaniques mesozoiques. II Int. Symp. Benthic Foraminifers, Pau (France), 1983.

Müller, G., and Gastner, M., 1971. The "Karbonate-Bombe," a simple device for determination of the carbonate content in sediments, soils and other materials. $N$. Jb. Miner. Mh., 10:466-469.

Okada, H., and Bukry, D., 1980. Supplementary modification and introduction of code numbers to the low-latitude coccolith biostrati- graphic zonation (Bukry, 1973, 1975). Mar. Micropaleontol., 5:321325 .

Pessagno, E. A., Jr., 1976. Radiolarian Zonation and Stratigraphy of the Upper Cretaceous Portion of the Great Valley Sequence, California Coast Ranges. Micropaleontology, Spec. Publ., 2.

1977. Upper Jurassic Radiolaria and radiolarian biostratigraphy of the California Coast Ranges. Micropaleontology, 23:56113.

Riedel, W. R., and Sanfilippo, A., 1971. Cenozoic radiolaria from the western tropical Pacific, Leg 7. In Winterer, E. L., Riedel, W. R., et al., Init. Repts. DSDP, 7, Pt. 2: Washington (U.S. Govt. Printing Office) $1529-1672$.

1978. Stratigraphy and evolution of tropical Cenozoic radiolarians. Micropaleontology, 24:61-96.

Ross, D. A., Neprochnov, Y. P., et al., 1978. Init. Repts. DSDP, 42, Pt. 2: Washington (U.S. Govt. Printing Office).

Roth, P. H., 1973. Calcareous nannofossils-Leg 17, Deep Sea Drilling Project. In Winterer, E. L., Ewing, J. I., et al., Init. Repts. DSDP, 17: Washington (U.S. Govt. Printing Office), 675-796.

1978. Cretaceous nannoplankton biostratigraphy and oceanography of the northwestern Atlantic Ocean. In Benson, W. E., Sheridan, R. E., et al., Init. Repts. DSDP, 44: Washington (U.S. Govt. Printing Office), 731-759.

1983. Jurassic and Lower Cretaceous calcareous nannofossils in the western North Atlantic (Site 534): biostratigraphy, preservation, and some observations on biogeography and paleoceanography. In Sheridan, R. E., Gradstein, F. M., et al., Init. Repts. DSDP, 76: Washington (U.S. Govt. Printing Office), 587-621.

Sanfilippo, A., and Riedel, W. R., 1980. A revised generic and suprageneric classification of the artiscins (Radiolaria). J. Paleontol. 54: 1008-1011.

Schaaf, A., 1981. Late early Cretaceous Radiolaria from the Deep Sea Drilling Project, Leg 62. In Thiede, J., Vallier, T. L., et al., Init. Repts. DSDP, 62: Washington (U.S. Govt. Printing Office), 419470.

Schlee, J. S., and Grow, J. A., 1980. Seismic stratigraphy in the vicinity of the COST No. B-3 Well. In Scholle, P. A. (Ed.), Geological Studies of the COST No. B-3 Well, United States Mid-Atlantic Continental Slope Area. U.S. Geological Survey, Circular 833:111116.

Shepard, F. P., 1954. Nomenclature based on sand-silt-clay ratios. $J$. Sed. Petrol., 24:151-158.

Sigal, J., 1977. Essai de zonation du Crétacé méditerranéen à l'aide des foraminifères planctoniques. Geol. Mediterr., 4(2):99-108.

Stainforth, R. M., Lamb, J. L., Luterbacher, H., Beard, J. H., and Jeffords, R. M., 1975. Cenozoic Planktonic Foraminiferal Zonation and Characteristics of Index Forms. Contrib. Univ. Kans., Article 62.

Thierstein, H. R., 1971. Tentative Lower Cretaceous calcareous nannoplankton zonation. Eclogae Geol. Helv., 64:459-488.

1973. Lower Cretaceous calcareous nannoplankton zonation. Abh. Geol. Bundesanst. (Wien), 29:1-52.

Tucholke, B. E., Ewing. J. I., and Schouten, H., 1982. Site survey report for Site ENA-3. Woods Hole Oceanographic Institution. Unpubl. report for JOIDES Site-Survey Panel.

van Hinte, J. E., 1976. A Cretaceous time scale. Am. Assoc. Pet. Geol. Bull., 60:498-548.

von Rad, U., Riech, V., and Rosch, H., 1978. Silica diagenesis in continental margin sediments off northwest Africa. In Lancelot, Y., Seibold, E., et al., Init. Repts. DSDP, 41: Washington (U.S. Govt. Printing Office), 879-905.

Wentworth, C. K., 1922. A scale of grade and class terms of clastic sediments. J. Geol., 30:377-390.

Date of Initial Receipt: 15 January 1985

Date of Acceptance: 17 October 1985 